Maurice A. Deane School of Law at Hofstra University Scholarly Commons at Hofstra Law

Hofstra Law Faculty Scholarship

2014

\title{
From the Rule of One to Shared Parenting: Custody Presumptions in Law and Policy
}

\author{
J. Herbie DiFonzo \\ Maurice A. Deane School of Law at Hofstra University
}

Follow this and additional works at: https://scholarlycommons.law.hofstra.edu/faculty_scholarship

\section{Recommended Citation}

J. Herbie DiFonzo, From the Rule of One to Shared Parenting: Custody Presumptions in Law and Policy, 52 Fam. Ct. Rev. 214 (2014) Available at: https://scholarlycommons.law.hofstra.edu/faculty_scholarship/520

This Article is brought to you for free and open access by Scholarly Commons at Hofstra Law. It has been accepted for inclusion in Hofstra Law Faculty Scholarship by an authorized administrator of Scholarly Commons at Hofstra Law. For more information, please contact lawcls@hofstra.edu. 


\title{
FROM THE RULE OF ONE TO SHARED PARENTING: CUSTODY PRESUMPTIONS IN LAW AND POLICY
}

\author{
J. Herbie DiFonzo ${ }^{1}$
}

Child custody presumptions have formed part of Anglo-American law for centuries. Both the paternal preference rule at common law and the tender years doctrine that supplanted it in the nineteenth century signaled the law's conviction that custody was indivisible: after a marital breakup, children could be entrusted to only one parent, with the other an infrequent visitor. This "rule of one" began to weaken in the last third of the twentieth century, as the movement toward gender equality called attention to the importance of both parents in the care and nurturance of children and loosened the link between gender and parenting role. Left without a presumption to direct their custody deliberations, courts turned — often by legislative fiat - to the more inclusive but less definitive best interests standard. Although sole custody decrees were still the norm, some courts began to see in joint custody an opportunity for a child to continue a strong and meaningful relationship with both parents. Courts, legislatures, and commentators are changing the vocabulary of child custody to reflect the evolving reality of twenty-first century family life. Parental responsibilities after separation or divorce are increasingly referred to as "decision-making" instead of "legal custody" and as "parenting time" in lieu of "physical custody." Calls for a 50/50 joint parenting time/physical custody presumption have sparked controversy. In some states, legislation already aims to ensure frequent and continuing parent-child contact with no specific temporal sharing formula. But putting any of these presumptions into effect in light of the statutory "best interests" concerns make the court's task-absent parental agreement—extremely complex. The interplay of domestic violence and "friendly parent" provisions with joint custody presumptions pose another array of complicating factors. Context is critical in assessing these statutory choices, on which no consensus currently exists. The task now is to avoid using the hard edge of legal presumptions to undermine the lived experience of children, while at the same time circumventing the perils of unpredictable case-by-case determinations unguided by presumptions or preferences. The most promising efforts chart a third course: nudging separating and divorcing parents into a framework that encourages them to implement shared parenting. Shifting the parental focus from litigating custody to jointly crafting a parenting plan also may serve to alleviate the worst aspects of the trauma children often experience when their parents break up.

Key Points for the Family Court Community:

- Until recently, child custody presumptions adhered to a "rule of one": courts generally insisted that only one parent could properly be awarded child custody.

- Child custody law is moving toward a norm of shared parenting, with frequent and continuing contact provided for each parent.

- Legal terminology is also shifting to encourage collaborative parenting. "Decision-making" is replacing "legal custody," and "physical custody" is giving way to "parenting time."

- A legal presumption of joint custody may mean no more than a generalized shared parenting arrangement, but applying the emerging statutes and case law to award joint custody can involve a quite complex determination process.

- Shifting the parental focus from litigating custody to implementing a shared parenting plan may avoid the pitfalls of litigating under the "best interests" standard either with or without a legal presumption.

Keywords: Child Custody; Decision Making; Parenting Plan; Parenting Time; Presumptions; and Shared Parenting.

\section{INTRODUCTION}

Presumptions have played a decisive role in child custody determinations. This article aims to place these presumptions in historical context as well as setting out their current scope and policy rationales, particularly in light of the current debate over joint custody presumptions and other

Correspondence: lawjhd@hofstra.edu 
proposals. This article is also intended to provide the historical and legal background for this Family Court Review Special Issue on the AFCC Think Tank Symposium on Closing the Gap: Research, Policy, Practice and Shared Parenting. Five years ago, two prominent scholars wrote about the many "paradigm shifts and pendulum swings" in child custody which had taken place in the preceding half-century. ${ }^{2}$ Those turbulent twists have only increased in momentum in recent years, and this article modestly hopes to set the landscape for further discussion.

\section{CHILD CUSTODY PRESUMPTIONS: AN HISTORICAL PRIMER}

At common law in matters of child custody, the English did much as the Romans did. Well into the late 18th century, ancient legal codes assured fathers of absolute dominion over children and property. ${ }^{3}$ Courts dealing with marital dissolution were primarily concerned with the allocation of material goods, and child custody doctrines evolved as a subset of property rights. ${ }^{4}$ Colonial Americans adapted these traditions to include a quid pro quo between father and child. ${ }^{5}$ The male parent retained a right to the physical custody, labor, and earnings of his children in exchange for the duty to support, educate, and train them to earn their own livelihoods. Since custody was originally incident to guardianship of lands, the father was seen as the natural guardian of the child. Thus, in virtually all cases, common law courts awarded sole custodial rights to the father, unless the court had determined the father to be an unfit parent. Colonial mothers, though deemed worthy of honor and deference, were not endowed with natural or legally enforceable parental rights and responsibilities.

Beginning in the late eighteenth century, English courts invoked the doctrine of parens patriae to sidestep paternal supremacy and further the welfare of children. Although a father's custodial right remained paramount, judges became more willing to balance a mother's childrearing capabilities against a father's superior economic and political standing. These equitable, less formalized familial notions took root in American courts, altering the concept of children as property and legitimating the parental role of women. While nineteenth-century American courts acknowledged the common law rule, they were confronted with two related cultural shifts: the industrial revolution's remaking men into marketplace wage earners and the emergence of a "separate sphere" for women as domestic caregivers. ${ }^{6}$

Mothers were seen as the instinctive custodians for both young children and those with disabilities. In following these dictates, courts crafted a "tender years" doctrine that allocated custody of young children to their mothers upon divorce or separation. A mother was "God's own institution for the rearing and upbringing of the child," and thus maternal custody placed "child culture in the hands of an expert."7 The nineteenth-century cult of domesticity extolled wifely virtues and elevated mother love to near-mythic heights. In the courts, paternal supremacy gave way to an almost reflexive and routine application of the tender years doctrine. Progressive Era legislation fortified the role of the state as parens patriae, increasing the power of judges to evaluate parental fitness, and thereby further undercutting absolute male authority within the household.

It took a social revolution to unseat the tender years doctrine and replace it with gender-neutral custody standards. Mounting divorce rates in the 1960s and ensuing decades provoked a lively debate about custody issues and parental roles. The movement for gender equality, along with the rise of father's rights groups, called attention to the importance of both parents in the care and nurturance of children, as well as a loosening of the link between gender and parental role. ${ }^{8}$ Meanwhile, the demise of the tender years doctrine left courts without a presumption to direct their custody deliberations. In lieu of gender-based theories, judges substituted the more inclusive but less definitive best interests standard. Unwittingly, courts succeeded in burdening themselves with case-by-case custody determinations, often involving a battle of experts, in lengthy and hotly contested custody litigation. What is more, the best interests standard seemed to many to engender a risk of excessive judicial discretion as well as a threat of inconsistency and subjectivity on the part of judges.

Courts in the 1970s began to realize that "the assumption a mother keeps the home, performs household duties, and will have more time to devote to the children and their welfare" was simply not true for many mothers. ${ }^{9}$ Gendered doctrines also yielded in the face of an emerging belief that "what 
a child needs is not a mother, but someone who can provide "mothering." "10 Despite the nearly universal abolition of a formal tender years presumption, however, "some judges [retain] a tendency to prefer that custody of young children be placed in the mother." ${ }^{\prime 1}$ Even courts articulating the best interests standard often hewed to the unwritten presumption "that the interests of children of tender years will be best served when they are in the custody of their mother." 12 A relic of the common law, it seems that the tender years doctrine is forgotten but not gone.

To varying degrees, states continue to weigh the primary caretaker's role in child rearing as a factor in making custody determinations. Some states have a presumption in favor of the "primary caretaker," ${ }^{13}$ while others have eliminated it. ${ }^{14}$ The primary caretaker presumption, while gender-neutral on its face, is broadly seen as achieving the same maternal preference results as the tender years doctrine. ${ }^{15}$ In many states, identifying the child's primary caregiver is a factor in the court's custody determination, but it is not entitled to presumptive weight. ${ }^{16}$

\section{FROM THE RULE OF ONE TO THE SHARING OF CUSTODY}

Both the paternal preference rule at common law and the tender years doctrine that supplanted it in the $19^{\text {th }}$ century signaled the law's conviction that custody was indivisible: after a marital breakup, children could properly be raised by only one parent, with the other parent entitled only to visitation. Illustrating this rule of one is a 1913 Arizona custody statute providing that "other things being equal, if the child is of tender years, it shall be given to the mother. If the child is of an age requiring education and preparation for labor or business, then to the father." ${ }^{17}$ Except in extreme cases, these legal conventions also avoided judicial evaluation of the welfare of the children whose custody was being determined. Unless the child would be placed in serious jeopardy through an award of custody to the legally favored parent, the paradigmatic custody rules at play until the late $20^{\text {th }}$ century allowed the courts to determine the result relatively easily by reference to broad legal norms. As the Alabama Supreme Court observed, courts throughout the country traveled "full circle in resolving the difficult questions surrounding child custody. At common law, courts spoke of the natural rights of the father. Now they speak of the instinctive role of the mother." ${ }^{18}$ In either case, the best interests of the child were assumed, not investigated.

Until the 1970s, courts regularly refused to order the sharing of custody between divorcing parents. As the Maryland Court of Appeals noted in 1934, the traditional objection to joint custody was that it "divided the control of the child, which is to be avoided, whenever possible, as an evil fruitful in the destruction of discipline, in the creation of distrust, and in the production of mental distress in the child." 19 The dominant view was that a child needed the stability of a single home run by only one parent, and that shifting the child from parent to parent would result in "a permanent injury to the child" by "constantly remind[ing him] that he is the center of a parental quarrel," and would not be "conducive to good citizenship." 20 Joint custody arrangements were nearly incomprehensible to most courts: "it is hardly possible for a child to grow up and live a normal, happy life under such circumstances." 21

The greater social and legal acceptance of joint custody in the 1970s came about when "parents began assuming more equal parenting responsibilities and [because] it served to avoid the 'win-lose' mentality of child custody disputes., ${ }^{22}$ In 1975, only North Carolina had a statute allowing for joint custody. ${ }^{23}$ Within a decade, thirty states had adopted similar laws. ${ }^{24}$ At the same time, courts in greater numbers began authorizing joint custody even without express statutory mandate, in light of the "[s]ignificant societal changes" in late twentieth-century America. ${ }^{25}$ These courts saw in joint custody an opportunity for a child to continue a strong and meaningful relationship with both parents, avoiding the treatment of one parent as merely a "visitor" to the child and possibly alleviating the trauma the child experienced in the marital dissolution.

In the 1980 s, the drive for gender equality in child custody practices dovetailed with efforts to mitigate the adversarial nature of divorce and family law proceedings. California, already a leader in promoting no-fault divorce and conciliation in domestic disputes, became the first state to legislate a 
preference for joint legal and physical custody. By 2013, thirty-six states have authorized joint custody, either by presumption, preference, or by adopting statutory language in support of cooperative parenting. ${ }^{26}$ The terminology of custody law changed to incorporate notions of "shared parenting" and "parenting plans" in place of the more rigid and proprietary "custody" and "visitation." As a matter of public policy, the phrase "frequent and continuing contact with both parents" appears in most state statutes with nearly mechanical regularity.

The risk inherent in a joint custodial arrangement is the creation of "confusion and instability for children at the very time they need a sense of certainty and finality in their lives," particularly if the parents are not committed to the substantial collaboration and communication required for the success of joint custody. ${ }^{27}$ Most courts and commentators agree with the oft-quoted dictum of the New York Court of Appeals that "joint custody is encouraged primarily as a voluntary alternative for relatively stable, amicable parents behaving in mature civilized fashion," while "[a]s a court-ordered arrangement imposed upon already embattled and embittered parents, accusing one another of serious vices and wrongs, it can only enhance familial chaos."28

In the frequent situation in which both parents are employed, joint custody can facilitate a more equitable sharing of the responsibilities of child rearing. But while the gender divide has narrowed in recent decades, it remains stubbornly real. A 2013 Pew Research Center study reports that "the time mothers spend on housework and child care is still about twice that of fathers." 29 Paid work, child care, and housework are not evenly distributed:

Overall, fathers spend significantly more hours each week in paid work than do mothers (40 hours vs. 23 hours, on average), while mothers' time in unpaid work (child care and housework) is much longer than that of fathers ( 31 hours per week vs. 17 hours). ${ }^{30}$

Depending on the family's circumstances, employment of both parents outside the home can make shared parenting after separation either a curse or a blessing.

\section{JOINT CUSTODY PRESUMPTIONS AND PREFERENCES TODAY}

As the Think Tank Final Report notes, "[t]he most significant trend in contemporary child custody law is toward greater active involvement by both parents in continued child rearing after separation." 31 This area is abuzz with legislative activity. Child custody statutes are frequently amended and bills regularly introduced calling for more changes. As one Canadian commentator noted, "[f]ollowing what has become an international common law trend identified in Australia, the United Kingdom, and the United States, Canadian custody and access decision making has become increasingly focused on maintaining parent/child access." ${ }^{32}$ New Zealand law has a similar focus. ${ }^{33}$

The applicability, appropriateness, and even the definition of joint custody are in a state of fluctuation. The term itself is often used rather loosely and confusingly in both popular journals and professional publications, including statutes and judicial opinions throughout the United States, the United Kingdom, Australia, Canada, and New Zealand. As the Maryland Court of Appeals once complained, "[t]he inability of courts and commentators to agree on what is meant by the term "joint custody' makes difficult the task of distilling principles and guidelines from a rapidly growing body of literature and case law. What one writer sees as an amorphous concept another sees as a structured legal arrangement." ${ }^{34}$

\section{(A) THE CHILD CUSTODY CONTINUUM}

In all states and many countries, the child's best interest is the paramount consideration in a custody determination. ${ }^{35}$ Nearly every state has established guidelines for determining the best interest of the child. Most have a fairly comprehensive set of statutory factors. ${ }^{36}$ In some states, case law has 
substantially expanded the general directions provided by the legislature. ${ }^{37}$ But there is no consensus as to the exact relationship between a determination regarding the best interests of the child and the ultimate determination regarding joint custody. In other words, there is no clear way to assign weight or value to individual best interest factors in an effort to calculate whether an award of joint custody will be assigned. As the Practice Commentaries to New York's custody statute suggest, "Since the court should always strive to do what is best for the child, the best interest of the child standard does not, on its own, offer much real guidance." ${ }^{\prime 38}$ Typically, a state's custody statute will list a number of factors for the court to assess, but will not prioritize these factors. ${ }^{39}$ The same multi-factor but open-ended analysis attends to child custody standards developed via case law. ${ }^{40}$

Many states and several countries have established either a statutory presumption in favor of joint custody or a policy preferring joint custody to sole custody. Behind these presumptions or preferences in favor of joint legal custody stands the public policy of assuring that children will have frequent and continuing contact with parents who have shown the ability to act in their best interests, and to encourage parents to share in the rights and responsibilities of raising their children after divorce or separation. $^{41}$

A number of scenarios have been swept under the joint custody umbrella: that both parents have legal custody (decision-making) but only one parent has physical custody (residence); that the parents share both legal and physical custody in approximately equal proportions; and that the parents share legal custody but one parent predominates in the residential placement of their child. This last scenario resembles the traditional sole custody award to one parent with visitation rights to the other. Even decreeing that physical custody will be equally shared opens the door to other questions: will the child spend alternate days (or weeks or fortnights or longer set periods) with each parent; will the child live with one parent on weekend and holidays while residing during school days with the other; or - a rare option - will the child live in the family home while each parent takes turns residing in it?

In light of these permutations, the joint custody-sole custody distinction is best viewed along a continuum, not as a sharp divide. Most states distinguish between joint legal and joint physical custody, allocating to the former the authority of both parents to participate equally in making significant long-term decisions regarding their child's health, education, and welfare. Joint physical custody implies that the child is in the physical care of both parents. But there is no accepted formula for how many hours per week, month, or year the child must reside with each parent for the arrangement to qualify as joint physical custody.

For example, Arizona's 2013 statute termed legal custody "legal decision-making," and defined it as "the legal right and responsibility to make all nonemergency legal decisions for a child including those regarding education, health care, religious training and personal care decisions." ${ }^{42}$ In lieu of physical custody, the lawmakers defined "parenting time" to mean "the schedule of time during which each parent has access to a child at specified times." ${ }^{.43}$ The court may order either sole or joint legal decision-making according to the best interests of the child. A parent who is not granted sole or joint legal decision-making must be afforded meaningful and continuing contact with the child unless the court finds such contact to be mentally, physically, morally or emotionally detrimental to the child. ${ }^{44}$ In determining the best interests of the child with regard to legal decisionmaking and parenting time, the court must consider all relevant factors, including the ten specific ones detailed in the statute. ${ }^{45}$ Further, in ascertaining the level of decision making that is in the child's best interests, the court must weigh an additional four statutory factors. ${ }^{46}$ But no formulas or minimum/maximum time periods are specified for the calculation of the appropriate duration or frequency of parenting time.

Forty-seven states and the District of Columbia have statutory provisions authorizing courts to award joint custody in one form or another (legal or physical). ${ }^{47}$ The remaining three states permit these orders through case law. ${ }^{48} \mathrm{~A}$ number of states have joint custody presumptions or preferences, while others have avoided either term and have instead directed that the courts order as much parenting time with each parent as is reasonably possible. ${ }^{49}$ The terminological vagaries make it strikingly difficult to fairly categorize these statutes, and any effort to assess their impact on family life based upon the statutory language alone would be foolhardy. All states continue to frame the custody 
resolution norm in terms of the best interests of the child, and therefore presumptions, preferences, and the other legal terms are subservient to that hallmark custody standard.

Statutory snapshots from Iowa and Arkansas illustrate the difficulties of generalizing in this area. Iowa's statute ostensibly lacks a custody presumption, noting only that the court "may" provide for joint custody. But the statute also insists that the court "shall" make a custody award-

which will assure the child the opportunity for the maximum continuing physical and emotional contact with both parents after the parents have separated or dissolved the marriage, and which will encourage parents to share the rights and responsibilities of raising the child unless direct physical harm or significant emotional harm to the child, other children, or a parent is likely to result from such contact with one parent. $^{50}$

This legislative drafting avoids the idiom of presumptions, but in its inclusive and sweeping language ("maximum continuing physical and emotional contact with both parents . . . which will encourage parents to share the rights and responsibilities of raising the child ...") it expresses a mandate for postseparation joint parenting to as great a degree as possible.

In 2013, Arkansas amended its child custody laws to indicate that joint custody is "favored" and defining it as "the approximate and reasonable equal division of time with the child by both parents individually as agreed to by the parents or as ordered by the court." 51 Whether "favored" will be interpreted as a presumption, a preference, or simply a general expression of public policy supportive of an increased role for the noncustodial parent remains to be seen. Initially, it seems most likely that the measure was intended to overrule the state judiciary's long-standing rule that joint custody was "disfavored." 52

\section{(B) CONSULTATION AND COLLABORATION VS. THE ONE-PARENT VETO}

The emphasis on mutual consultation and collaboration has led courts to refuse to sanction joint custody when parental cooperation and communication are lacking. The Nebraska Supreme Court affirmed a lower court finding that "because the parents were unable to communicate face-to-face and because there is a level of distrust between the parents, joint decision making by the parents was not in the child's best interests. ${ }^{.53}$ This principle is abundantly established in case law. ${ }^{54}$ But some states specifically do not allow a parent to employ a unilateral veto on joint custody. The Missouri legislature has determined that "joint physical and joint legal custody . . . shall not be denied solely for the reason that one parent opposes a joint physical and joint legal custody award." 55 Similarly, an Alabama statute provides that a court "may order a form of joint custody without the consent of both parents, when it is in the best interest of the child." ${ }^{56}$ A Louisiana statute establishes a rebuttable presumption that joint custody is in the best interests of the children, and a parent who objects to joint custody bears the burden of rebutting the presumption. ${ }^{57}$ While these conflicting signals may be reconciled as consistent with the best interests principle, the difficulties in application of multiple and ambiguous standards continue to cloud the issue..$^{58}$

Rebutting the joint custody presumption involves more than merely showing disagreement. Courts have often looked beyond parental disharmony to order joint custody when in the child's best interests. The general rule is that mutual hostility will not doom a joint custody arrangement if the parents are able "to set aside their personal feelings for the best interest of the children when required." 59 Obviously, each case draws upon its own factual context when the two essential components of successful shared parenting are assessed: "One is a strong commitment to cooperate. The other is a capacity to engage in the cooperation required." 60

\section{(C) JOINT LEGAL CUSTODY/DECISION-MAKING PREFERENCES}

Some states have articulated a preference — not a presumption —-for joint legal custody through their statutory schemes, legislative policy declarations, or case law. ${ }^{61}$ These expressed preferences 
require courts to keep joint legal custody "on the table" and encourage parents to share in the responsibilities of rearing their children. Sometimes the language is mildly hortatory: "The court shall assure minor children of frequent and continuing contact with both parents, when appropriate, and encourage parents to share in the responsibilities of rearing their children." ${ }^{\prime 62}$ At other times, the preference is stated directly ("Joint legal custody is preferred"63), but conditioned by the commonsense necessity that parents can "cooperate and communicate."

Kansas's custody statute mandates a preference for joint custody by listing joint custody ahead of sole legal custody "in the order of preference." ${ }^{\prime 5}$ By contrast, Georgia has enacted a statutory preference in favor of joint custody that is less directly expressed but so understood in the case law. The Georgia custody statute begins by disavowing any presumption "in favor of any particular form of custody, legal or physical." ${ }^{96}$ But a subsequent provision sets out "the express policy of this state to encourage that a child has continuing contact with parents . . . and to encourage parents to share in the rights and responsibilities of raising their child after such parents have separated . . " ${ }^{67}$ The Georgia Supreme Court has held that enforcing the legislative policy favoring shared rights and responsibilities between parents requires the trial court to give " "due consideration' to the feasibility of a joint custody arrangement." $" 68$

Many states have no presumption or preference with regard to joint legal custody. Hawaii's statutory scheme lays out the issue in neutral terms, directing the court that it should award custody to either or both parents according to the child's best interests standard, and that it "also may consider frequent, continuing, and meaningful contact of each parent with the child unless the court finds that a parent is unable to act in the best interest of the child. . . ${ }^{99}$ A recent Arizona statute evenhandedly states that the court "may order sole legal decision-making or joint legal decisionmaking." " But in "determining the level of decision-making that is in the child's best interests," the court must consider the eleven factors prescribed for the initial legal decision-making allocation, as well as four additional factors. ${ }^{71}$ Although Arizona's statute expresses no presumption or preference for joint legal custody, it requires the court, "[c]onsistent with the child's best interests," to "adopt a parenting plan that provides for both parents to share legal decision-making regarding their child and that maximizes their respective parenting time." 72 The legislative goal of ensuring that both parties retain their parenting roles as much as possible post dissolution is also apparent in the provision that a "parent who is not granted sole or joint legal decision-making is entitled to reasonable parenting time to ensure that the minor child has substantial, frequent, meaningful and continuing contact with the parent." 73

Finally, some states have an explicit preference against joint legal custody. ${ }^{74}$ Other states make it clear that, absent complete accord between the parents, trial judges are forbidden to allocate decisionmaking responsibility jointly. ${ }^{75}$ Courts also view parental pledges of forthcoming good behavior in the light of judicial experience with the conflicts experienced by many divorcing couples. As an Illinois appellate court stated, "we view joint custody as most extraordinary and counsel skepticism when trial courts hear promises from newly divorcing parents that they can surmount the manifest difficulties of a joint-custody order." 76

\section{(D) JOINT PHYSICAL CUSTODY/PARENTING TIME DETERMINATIONS}

A generation ago, New York's highest court announced its perspective on joint physical custody in what has come to be known as the "Braiman rule." "77 The court asserted that "alternating physical custody" would generally "further the insecurity and resultant pain frequently experienced by the young victims of shattered families." Thus, the court viewed joint custody as "a voluntary alternative for relatively stable, amicable parents behaving in mature civilized fashion." But the court warned that as "a court-ordered arrangement imposed upon already embattled and embittered parents, accusing one another of serious vices and wrongs, [joint custody] can only enhance familial chaos." 78

Although this assessment dates from 1978, New York and other courts still consider those same "relatively stable, amicable parents behaving in mature civilized fashion" 79 to be the gold standard for 
participants in joint custody. The other half of the Braiman rule has also continued in force as the well-established principle "that joint custody is not appropriate where the parties are antagonistic toward each other and have demonstrated an inability to cooperate in matters concerning the child, even if the parties have agreed to the joint custody arrangement." ${ }^{\text {" }}$

In contrast to the major decision-making components at the heart of legal custody, physical custody generally means "the right and obligation to provide a home for the child and to make the day-to-day decisions required during the time the child is actually with the parent having such custody." ${ }^{\prime 11}$ When physical custody is entrusted to the parents jointly, it is generally "divided" custody, as each parent normally has a separate residence to which the child travels. ${ }^{82}$ Divided physical custody will rarely be equally divided, and "most commonly will involve custody by one parent during the school year and by the other during summer vacation months, or division between weekdays and weekends, or between days and nights." 83

Nor should an award of joint legal custody be seen as the prologue to joint physical custody. In the words of the recently-enacted Arizona statute, "[s]hared legal decision-making does not necessarily mean equal parenting time." ${ }^{, 4}$ Logistical and other practical reasons generally lead to the far greater frequency of joint legal than joint physical custody awards, especially if the latter involves a 50/50 split of the children's time between the parents. ${ }^{85}$

\section{(E) TEMPORAL FORMULAS FOR PARENTING TIME?}

Most often, as in Missouri's statute, a joint custody order awards "each of the parents significant, but not necessarily equal, periods of time during which a child resides with or is under the care and supervision of each of the parents." 86 The Missouri law tracks the modern trend defining joint physical custody as a mechanism for ensuring "frequent, continuing and meaningful contact" between the child and both parents. ${ }^{87}$ Similarly, the Massachusetts statute provides that a child should have "periods of residing with and being under the supervision of each parent" with the usual proviso "that physical custody shall be shared by the parents in such a way as to assure a

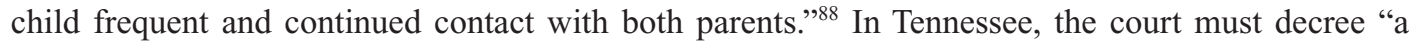
custody arrangement that permits both parents to enjoy the maximum participation possible in the life of the child" consistent with a bevy of factors, including ten specified criteria pertaining to the best interests determination, as well as "the location of the residences of the parents, the child's need for stability and all other relevant factors." $" 89$

Even where the legislature has created a statutory presumption in favor of joint physical custody, judges retain wide discretion on how to allocate parenting time. For example, California law contains a presumption in favor of "joint custody," a term which encompasses both joint legal and physical custody, when both parties agree. ${ }^{90}$ But the presumption is subject to the statutory multi-factor best interests analysis. ${ }^{91}$ And joint physical custody "means that each of the parents shall have significant periods of physical custody," and is to be "shared by the parents in such a way so as to assure a child of frequent and continuing contact with both parents . .."92 Idaho law similarly includes a presumption that joint custody, both legal and physical, is in the best interests of the child "absent a preponderance of the evidence to the contrary." ${ }^{93}$ But the legislature made it clear that its focus was not parental equality but rather ensuring "significant periods of time in which a child resides with or is under the care and supervision of each of the parents. ..." ${ }^{94}$ The legislative instructions equip the courts with broad discretion to craft the actual arrangements, adding the caution that joint physical custody "does not necessarily mean the child's time with each parent should be exactly the same in length nor does it necessarily mean the child should be alternating back and forth over certain periods of time between each parent." ${ }^{95}$

Statutory terms directing that parenting time be allocated equally are often interpreted by the courts to mean less than the words suggest. For example, Louisiana's statute provides that " $[t]$ o the extent it is feasible and in the best interest of the child, physical custody of the children should be shared equally." 96 But the state's appellate courts have held that, despite the "shared equally" language in the statute, "[s]ubstantial time rather than strict equality of time is mandated by the legislative scheme 
providing for joint custody of children." ${ }^{97}$ Substantial rather than literal equality is also at the heart of Georgia's statute, which defines joint physical custody to mean "that physical custody is shared by the parents in such a way as to assure the child of substantially equal time and contact with both parents." 98

While most states have eschewed temporal formulas, several have mandated specific residential custody percentages under certain circumstances. In interpreting state statutes calling for "frequent associations and a continuing relationship with both parents" after separation or divorce, ${ }^{99}$ the Nevada Supreme Court has determined that joint custody means that each parent must have physical custody of the child at least 40 percent of the time, or 146 days per year." ${ }^{100}$ Utah law defines joint physical custody to mean "the child stays with each parent overnight for more than $30 \%$ of the year." 101 The Utah Legislature has also enacted a series of guidelines intended "to promote parent-time at a level consistent with all parties' interests." 102 These include a minimum parent-time schedule for children aged 5 to 18 years and one for children under 5 years old." ${ }^{103}$ An order of parent-time conforming to the statutory guidelines is "presumed to be in the best interests of the child" unless "a parent can establish ... by a preponderance of the evidence that more or less parent-time should be awarded under statutory criteria." 104

Minnesota law incorporates a "rebuttable presumption that a parent is entitled to receive at least 25 percent of the parenting time for the child." 105 Calculating what this formula means in the life of a child is not an easy task. The statute provides a method for determining 25 percent of parenting time that allows for alternative counting measures and implies that a strict computation may at times be impracticable:

[T]he percentage of parenting time may be determined by calculating the number of overnights that a child spends with a parent or by using a method other than overnights if the parent has significant time periods on separate days when the child is in the parent's physical custody but does not stay overnight. The court may consider the age of the child in determining whether a child is with a parent for a significant period of time..$^{106}$

West Virginia's approach to joint custody is unusual in that the state has adopted the "approximation" approach to shared parenting proposed by the American Law Institute in its Principles of Family Dissolution. ${ }^{107}$ The statute provides that " $[\mathrm{u}]$ nless otherwise resolved by agreement of the parents ... or unless manifestly harmful to the child, the court shall allocate custodial responsibility so that the proportion of custodial time the child spends with each parent approximates the proportion of time each parent spent performing caretaking functions for the child prior to the parents' separation or, if the parents never lived together, before the filing of the action. ..."108 The statute subjects the approximation rule to a best interests standard with eight specific factors, allowing the court to deviate from the approximation rule as appropriate. ${ }^{109}$

In Texas, if the court appoints the parents as "joint managing conservators" of the child, it must "designate the conservator who has the exclusive right to determine the primary residence of the child. ..." "110 But the court must also "specify the rights and duties of each parent regarding the child's physical care, support, and education" and "allocate between the parents, independently, jointly, or exclusively, all of the remaining rights and duties of a parent. ..." ${ }^{\prime 11}$ The Texas Family Code provides, however, that "[ $\mathrm{t}] \mathrm{h}$ he best interest of the child shall always be the primary consideration of the court in determining the issues of conservatorship and possession of and access to the child." 112

\section{THE UNCLEAR LEGAL EFFECT OF JOINT CUSTODY PRESUMPTIONS}

What does a joint physical custody presumption actually mean? Generally, it aims at ensuring frequent and continuing parent-child contact with no specific sharing formula. Idaho's provision is typical - a statutory presumption that joint custody (both legal and physical) is in the child's best interests. ${ }^{113}$ The statute emphasizes that joint physical custody "does not necessarily mean the child's 
time with each parent should be exactly the same in length nor does it necessarily mean the child should be alternating back and forth over certain periods of time between each parent." 114 Trial courts retain a great deal of discretion, particularly since the statute commands them to determine " $\mathrm{t}] \mathrm{he}$ actual amount of time with each parent. ..."115

The California Legislature has decreed it a matter of public policy to assure children of substantial contact with both parents post-dissolution and to promote shared parenting unless it would be contrary to the child's best interests. ${ }^{116}$ California statutes contain a presumption that joint custody (both legal and physical) is in the best interests of the child when the parents have agreed to it. ${ }^{117}$ Joint physical custody means "that each of the parents shall have significant periods of physical custody" and it "shall be shared by the parents in such a way so as to assure a child of frequent and continuing contact with both parents. ..."118 The statute does not provide any temporal determinants or formulas to assess whether the presumption is being properly applied. ${ }^{119}$

Joint custody presumptions in several states are triggered by parental agreement. ${ }^{120}$ For example, the Tennessee statute indicates that when parents agree to joint custody, a contrary finding by the court requires "clear and convincing evidence to the contrary." 121 This burden shifting is typical, since the presumption is often phrased in terms of the allocation of the burden of proof. ${ }^{122}$ The degree of difficulty in carrying this burden depends on the court's view of the evidence suggesting the likelihood of continued parental agreement. Tennessee's courts have interpreted this to mean that joint custody arrangements are appropriate only where a "harmonious and cooperative relationship" exists between both parents. ${ }^{123}$ Tennessee's traditional hostility to joint custody is glaringly apparent: "While we have stopped short of rejecting this type of custody arrangement outright, divided or split [i.e., joint] custody should only be ordered when there is specific, direct proof that the child's interest will be served best by dividing custody between the parents."124

West Virginia offers a different condition precedent to a presumption in favor of joint decisionmaking. The West Virginia statute holds that if each of the child's parents has been "exercising a reasonable share of parenting functions for the child, the court shall presume" that joint legal custody is in the child's best interests. ${ }^{125}$ As with other joint custody presumptions, it can be rebutted if there is a history of domestic abuse or by a showing that joint allocation of decision-making responsibility is not in the child's best interest. ${ }^{126}$

Nebraska courts may award "joint physical custody or joint legal custody, or both . . regardless of any parental agreement or consent." 127 The court is authorized to override the wishes of either or both parents as long as it makes the specific finding that the award is in the best interests of the child after a hearing in open court. ${ }^{128}$ These provisions were added by the state legislature in 1993 to overrule a state supreme court decision that required the agreement of both parents in order to award joint custody. ${ }^{129}$ However, Nebraska appellate courts continue to insist upon "the longstanding rule that joint custody is not favored by the courts of this state and will be reserved for only the rarest of cases." 130

Some states explicitly disavow any joint custody presumption, legal or physical. ${ }^{131}$ Other states' statutes are silent on the question, implying that the courts have wide discretion to craft a custodial arrangement in the best interest of the children. ${ }^{132}$ In either circumstance, trial courts are called upon to apply a multi-factor test in making the "best-interest" custody decisions.

\section{(A) INTRICACIES OF A JOINT DECISION-MAKING PRESUMPTION: THE NEW MEXICO EXAMPLE}

Several states have a rebuttable statutory presumption that an allocation of decision-making responsibility to both parents jointly is in the best interest of the child. ${ }^{133}$ The operation of the joint decision-making presumption is a complex process. By way of illustration, consider the New Mexico framework. Its statute mandates "a presumption that joint custody is in the best interest of the child in an initial custody determination." ${ }^{134}$ But the statute carefully calibrates this presumption by subjecting it to a number of other provisions. A court considering joint custody is required first to weigh 
the regular statutory standards for the determination of child custody, and then to consider nine additional factors exclusive to joint custody. ${ }^{135}$ The court is constrained not to "prefer one parent as a custodian solely because of gender." ${ }^{136}$ If the court does order joint custody, it "may specify the circumstances, if any, under which the consent of both legal custodians is required to be obtained in order to exercise legal control of the child and the consequences of the failure to obtain mutual consent." 137

The New Mexico statute also emphasizes the importance of parenting plans by providing that joint custody may not be ordered unless the court has approved a parenting plan beforehand. ${ }^{138}$ The parenting plan must include "a division of a child's time and care into periods of responsibility for each parent." 139 The statute details five other provisions that may be included in the approved parenting plan:

1) statements regarding the child's religion, education, child care, recreational activities and medical and dental care;

2) designation of specific decision-making responsibilities;

3) methods of communicating information about the child, transporting the child, exchanging care for the child and maintaining telephone and mail contact between parent and child;

4) procedures for future decision-making, including procedures for dispute resolution; and

5) other statements regarding the welfare of the child or designed to clarify and facilitate parenting under joint custody arrangements. ${ }^{140}$

An award of joint custody does not imply an equal division of parenting time or financial responsibility for the child. ${ }^{141}$ Each parent with joint custody is "expected to carry out [] responsibility for the child's financial, physical, emotional and developmental needs during that parent's periods of responsibility." ${ }^{142}$ The parents' obligation to consult with one another before making a major child welfare decision is stated explicitly: "[N]either parent shall make a decision or take an action which results in a major change in a child's life until the matter has been discussed with the other parent and the parents agree." 143 Further detailed provisions spell out notification and other requirements regarding a parent's change of residence, the child's religious affiliation and activities, educational decisions and access to the child's school records, medical and dental providers, and the child's recreational activities. ${ }^{144}$ The statutory scheme also provides seven options for making "decisions regarding major changes in a child's life." 145 These include mediation and family counseling requirements, allocating final decisional authority on a matter to one party, terminating joint custody, as well as a binding arbitration and court decision options. ${ }^{146}$

In sum, the joint custody presumption in New Mexico is far from straightforward or simple. It requires the trial court to engage in an intricate weighing of numerous statutorily required and fairly detailed factors. It also entails parental commitment to a well-articulated parenting plan for allocating the child's time and activities, as well as to very specific provisions for parental decision-making with regard to disputes or major changes to the child's life.

\section{(B) CONCEPTUAL AND PRACTICAL PROBLEMS WITH PRESUMPTIONS}

A presumption is generally defined as "a legal inference or assumption that a fact exists, based on the known or proven existence of some other fact ..."147 What precise burden of proof is shifted by a presumption is a matter of some debate. Under the Federal Rules of Evidence, "the party against whom a presumption is directed has the burden of producing evidence to rebut the presumption. But this rule does not shift the burden of persuasion, which remains on the party who had it originally." ${ }^{48}$ But under the Uniform Rules of Evidence, a presumption "imposes on the party against whom it is directed the burden of proving that the nonexistence of the presumed fact is more probable than its existence." 149 In general, a rebuttable presumption is "[a]n inference drawn from certain facts that establish a prima facie case, which may be overcome by the introduction of contrary evidence." 150 
How would a joint custody presumption apply? It would likely require the party opposing joint custody to produce sufficient evidence to rebut the presumption and thus shift the burden of persuasion to the party opposing joint custody. One commentator has suggested that "rather than treating both parents equally ... a presumption would actually disfavor the parent opposing joint custody."151 This is true, but tipping the scales toward shared parenting no matter which parent favors or opposes it is surely the legislative aim, provided it is in the child's best interests. Whether joint custody actually benefits children in most cases is, as yet unresolved. Unless carefully crafted, a joint custody presumption "would greatly minimize the custody factors that a court is required to consider and dilute or eliminate the best-interest-of-the-child standard." 152

Some states have enacted a presumption that joint custody is in the best interests of the child if both parents request it. ${ }^{153}$ This type of presumption belabors the obvious: parents generally decide what is in their children's welfare without state intervention. There is no policy reason why the act of separating or divorcing should result in abrogating parents' rights to raise their children. Judicial authority is needed only when parents cannot agree on child welfare issues. ${ }^{154}$ Prudence in the light of experience should dictate, however, that given the hostility and overreaching that accompanies so many divorces, a court should retain the discretion to ensure that the parents' agreements have been reached voluntarily.

Joint custody presumptions that exceed parental agreement may be testing the limits of current social science research. Almost thirty years ago, Elizabeth Scott and Andre Derdeyn identified the two key assumptions of these more expansive joint custody presumptions, that parents will "be able to cooperate in raising their child, regardless of whether or not they freely decided upon joint custody," and that "the harm to the child caused by any interparental conflict will be outweighed by the benefit of continuing a parent-child relationship with both parents." 155 These assumptions continue to be "problematic." ${ }^{156}$ Margaret F. Brinig has summarized the recent experiences of the states with joint custody presumptions:

\footnotetext{
Although strong presumptions of joint custody were popular in the 1980s when several states adopted them, the more recent practice, after some twenty years' experience, has been to allow joint custody as one of several options, rather than to presume that it is in the best interests of children. In other words, after experimentation with joint custody, some states have realized that continual moving between households may be harmful to children, that the bulk of newly divorced spouses cannot remain as positively involved with each other on an everyday basis as joint physical custody requires, or that the presumption is causing more litigation to already crowded dockets. ${ }^{157}$
}

\section{DOMESTIC VIOLENCE, "FRIENDLY PARENT" PROVISIONS, AND JOINT DECISION-MAKING}

A presumption in favor of joint legal custody is typically rebutted, or reversed, if domestic abuse has occurred. State legislatures have generally declared that "domestic abuse renders joint legal or physical custody inconsistent with the best interests of the child." 158 These legislative enactments have been passed at a time of increasing national awareness of the harmful effects on children in family relationships where domestic violence is present. ${ }^{159}$ In 1994 the National Council of Juvenile and Family Court Judges, promulgated the Model Code on Domestic and Family Violence which recommended that a court finding of domestic or family violence "raises a rebuttable presumption that it is detrimental to the child and not in the best interests of the child to be placed in sole custody, joint legal custody, or joint physical custody with the perpetrator of family violence."160

Currently, all fifty states and the District of Columbia require courts making a custody determination to consider domestic violence by one parent against the other. ${ }^{161}$ Twenty-eight states include domestic abuse as a factor for the court to consider. Twenty-two states and the District of Columbia go further, creating a rebuttable presumption against awarding joint custody to the perpetrator of domestic violence. ${ }^{162}$ 
The effectiveness of these exceptions to custody presumptions has been challenged. Some commentators argue that the statutory framework is problematic because it "puts the burden of proving domestic violence on the victim of that violence." 163 Intimate partner abuse tends to be invisible and rarely reported, and despite the clear statutory mandate, courts often fail to fully account for domestic abuse. ${ }^{164}$ At the same time, concerns have been raised about the extent of false allegations of domestic violence that can serve to corrupt the court's parenting determination process.

To promote active participation by both parents after separation, many states have amended their best interest factors to include "friendly parent" provisions. This assumption favors the parents more apt to encourage contact with the other parent. The rationale is straightforward: children are thought to do better when both parents continue to raise them; thus, if one parent will not allow the other to play that critical role and the other will, the "friendly parent" should have an advantage in the custody battle. ${ }^{165}$

Some commentators have warned against using "friendly parent" provisions to trump evidence of domestic violence. ${ }^{166}$ They warn of judicial rulings that "encourage cooperative parenting [even] in cases where increased contact may exacerbate conflict levels." 167 Some statutes attempt to address these concerns by declaring that the friendly parent provision does not apply in cases involving domestic violence. ${ }^{168}$

\section{WHAT'S IN A NAME? THE NEW PARENTING PLAN NOMENCLATURE}

Some states now reject the traditional terminology of child custody with its possessory overtones. ${ }^{169}$ Legislatures, courts, and mental health professionals are in the process of exchanging the common law language for terms evocative of mutual parental involvement. Postseparation parenting responsibilities are increasingly addressed as decision-making and parenting time, and parents are often held responsible for drafting parenting plans to structure those decisions as they are reconstituting their families.

More than the lexicon is at stake. The aim is forthrightly a culture change, exemplified by the 2006 Australian law reforms which aimed to shift postseparation parenting from adversarial to collaborative. ${ }^{170} \mathrm{~A}$ small but growing number of legislatures have jettisoned the traditional nomenclature, a development nudged along by the American Law Institute's issuance in 2002 of its Principles of the Law of Family Dissolution. The Principles embodied several key terminological changes, such as "allocation of custodial and decision-making responsibilities for children," and "parenting plan."171 Ohio statutes, for example, describe a custody dispute as a "proceeding pertaining to the allocation of parental rights and responsibilities for the care of a child," 172 and refer to joint custody as "shared parenting." 173 Minnesota has substituted a "parenting time" decision for the former decree allocating residential custody and visitation. ${ }^{174}$ Similarly, divorcing Colorado parents now have a proceeding "concerning the allocation of parental responsibilities." ${ }^{175}$ Physical custody in that state has been replaced by a "[d]etermination of parenting time," and legal custody is now the "[a]llocation of decision-making responsibility." 176

"Parenting time" describes the periods of time each parent spends with the child as outlined in a "parenting plan." These plans aim to achieve the public policy goal that children have frequent and continuing contact with both parents. These plans may be crafted from scratch by the parents, or they may be customized from a menu of sample plans available from court or private organization websites. They should be flexible but fairly detailed, setting out each parent's area of responsibility in providing for the child's residential and physical care as well as emotional well being, both at the time the plan goes into effect and as the child ages and matures. ${ }^{177}$ Ideally, these plans should also recognize the likelihood of future parenting disputes by incorporating problem-solving mechanisms, such as mediation, collaborative law, parent coordination, and arbitration, with adjudication in court only as a last resort.

As the Washington Supreme Court noted, "[t]he key advantage of the parenting plan concept over the former law's custody concept is the parenting plan's ability to accommodate widely differing 
factual patterns and to allocate parental responsibility accordingly."178 Development of a parenting plan is a significant family law mechanism created in response to the "persistent dissatisfaction with the traditional adversarial divorce process" and intended to encourage "models emphasizing selfdetermination and problem-solving approaches." ${ }^{\text {179 }}$ In the last generation, family courts have moved "towards a philosophy that supports collaborative, interdisciplinary, interest-based dispute resolution processes and limited use of traditional litigation." 180 In short, as Francis J. Catania, Jr. has argued, parenting plans aim "at reversing the trend toward the clean break as a social norm in child custody dispute resolution." "181 The separation of the parents from each other need not mean the parting of the parents from their children.

Many state statutes require a parenting plan as part of the process for obtaining joint custody. ${ }^{182}$ Additionally, some state courts may require the parents to submit a plan to implement a joint custody order. ${ }^{183}$ Some jurisdictions have also instituted parenting coordination programs "to provide a child-focused alternative dispute resolution process ..." 184 The range and comprehensiveness of parenting plan provisions may be seen in the Arizona law requiring inclusion of the following:

1. A designation of the legal decision-making as joint or sole ...

2. Each parent's rights and responsibilities for the personal care of the child and for decisions in areas such as education, health care and religious training.

3. A practical schedule of parenting time for the child, including holidays and school vacations.

4. A procedure for the exchanges of the child, including location and responsibility for transportation.

5. A procedure by which proposed changes, disputes and alleged breaches may be mediated or resolved, which may include the use of conciliation services or private counseling.

6. A procedure for periodic review of the plan's terms by the parents.

7. A procedure for communicating with each other about the child, including methods and frequency.

8. A statement that each party has read, understands and will abide by the notification requirements [pertaining to the sexual offenders registration law]. ${ }^{185}$

Many state statutes contain similarly detailed provisions for parenting plans. ${ }^{186}$ Parenting plans have become the preferred method to achieve the public policy goal that children have "frequent and continuing contact" with both parents, ${ }^{187}$ and they are an integral component for millions of worldwide parenting resolutions. ${ }^{188}$

\section{SHARED PARENTING PRESUMPTIONS, PREFERENCES, AND FACTORS: A SCHEMA OF CHOICES}

The landscape for shared parenting is in legal and cultural transition. But it may be useful to view the blueprint for evolving legislation as having three sets of options on shared parenting: a legal presumption for shared parenting; a preference for shared parenting, and conditioning shared parenting upon the best interests of the child. What follows below is an effort to capture this moment in child custody law, drawing upon the leading edge of statutory development. After the core elements are described and defined, each set contains options relating to decision-making and parenting time. While this schema is annotated, no effort has been made to replicate a full statute.

\section{Core Emerging Statutory Elements}

\section{A. Basic Principles}

Best Interest of the Child Standard: The child's best interest, including health, safety, and welfare, is the paramount consideration in a decision-making and parenting time determination. ${ }^{189}$ Frequent, continuing, and meaningful contact with both parents is 
in the child's best interests in most circumstances. ${ }^{190}$ The court shall ensure that the parenting plan agreed to by the parents is consistent with the child's best interests. In the event that the parents do not agree on a parenting plan, the court shall adopt a parenting plan that, consistent with the child's best interests, provides for both parents to share legal decision-making regarding their child and that maximizes their respective parenting time. ${ }^{191}$

Abusive behavior: The "perpetration of child abuse or domestic violence in a household where the child resides is detrimental to the child." 192

Parental gender irrelevant: No preference shall be given to either parent because of that parent's gender. ${ }^{193}$

Preference for Alternative Dispute Resolution: Litigation should be used as a last resort, after mediation and other dispute resolution methods have been seriously attempted. ${ }^{194}$

B. Definitions

Parenting Plan: A parenting plan allocates legal decision-making and parenting time. ${ }^{195}$ A parenting plan sets out the responsibility of each parent in providing for the child's care both at the time of implementation and as the child ages and matures. ${ }^{196} \mathrm{~A}$ parenting plan must contain provisions for the resolution of future disputes between the parents, initially through non-adversarial dispute resolution methods. ${ }^{197}$

Legal Decision-making: Legal decision-making (formerly known as legal custody) refers to the legal right and responsibility to make all nonemergency legal decisions for a child including those regarding welfare, education, health care, and religious training. Joint legal decision-making means that both parents share all parental rights, privileges, duties, powers, responsibilities, and obligations, except for specified decisions as set forth in the parenting plan. ${ }^{198}$

Parenting Time: Parenting time (formerly known as physical custody) shall be allocated in the parenting plan in a manner to assure the child of frequent, continuing and meaningful contact with both parents. Joint parenting time allocation means that the parents have significant periods of time during which a child resides with or is under the care and supervision of each of the parents. These periods of time are not necessarily equal, but must result in the child staying with each parent overnight for more than thirty percent of the year. ${ }^{199}$

II. Shared Parenting Determinations: Presumptions, Preferences, and Best Interests Factors

A. Presumptions Options

A1: Joint Legal Decision-Making Presumption

Joint legal decision-making is presumed to be in the best interests of a child in an initial determination, except in cases where the court finds any of the following:

a) Domestic violence in the home or in the presence of the child;

b) Particular physical or mental needs of a parent or child, making joint legal decision making inadvisable;

c) Geographical distance between the residences of the parents, making joint decision making impractical; or

d) Any other factor the court considers relevant. ${ }^{200}$

A2: Joint Parenting Time Allocation Presumption

Joint parenting time allocation is presumed to be in the best interests of a child in an initial determination, except in cases where the court finds any of the following:

a) Domestic violence in the home or in the presence of the child;

b) Particular physical or mental needs of a parent or child, making joint legal custody inadvisable;

c) Geographical distance between the residences of the parents, making joint parenting time allocation impractical; or

d) Any other factor the court considers relevant. ${ }^{201}$ 
B. Preferences Options

B1: Joint Legal Decision-Making Preference

Legal decision-making authority should be granted in the following order of preference according to the best interest of the child:

a) Jointly to the parents;

b) Specific areas of responsibility allocated to each parent;

c) Solely to either parent. ${ }^{202}$

B2: Joint Parenting Time Allocation Preference

Parenting time should be allocated in the following order of preference according to the best interest of the child:

a) Jointly to the parents;

b) Primarily to one parent, with the other parent entitled to parenting time to ensure that the child has frequent, meaningful, and continuing contact with that parent. ${ }^{203}$

C. Best Interests Factors Options

C1: Joint Legal Decision-Making Factors

Legal decision-making authority should be granted according to the best interest of the child as set forth in the jurisdiction's statute and case law.

C2: Joint Parenting Time Allocation Factors

Parenting time should be allocated according to the best interest of the child, with each parent in most circumstances receiving frequent, meaningful, and continuing contact with the child.

\section{CONCLUSION}

Context is critical in assessing these statutory choices. Yet the ground of decision has never been more complex, with no consensus regarding how joint custody is defined, how it is awarded, or how precisely joint parenting time and decision-making interact. All insist that the child's best interest is of paramount concern, and all agree that children generally do best when both parents remain active in their lives. Yet, like Odysseus, our society and legal system must traverse the conflicts between twin dangers. Our Scylla, using the hard edge of legal presumptions to determine parental disputes, risks a mismatch between the paper statute and the flesh-and-blood family, and arguably increases litigation. Our Charybdis, rejecting presumptions and preferences to rely solely on case-by-case determinations, undermines predictability and also arguably increases litigation. As discussed in this Article, the most promising efforts may chart a third course: nudging separating and divorcing parents out of litigation and into a framework that both allows and encourages them to concentrate on mapping out a future with their children. Our culture is moving in the direction of increasingly shared parenting. The legal system needs to do its best to facilitate that process.

\section{NOTES}

1. My thanks to three stellar research assistants whose prodigious labors made this Article possible, Kristin Pezzuti, Nicole Guliano, and Diana Rivkin. Thanks especially to Ruth C. Stern, whose writing acumen and editorial eye are unsurpassed; and to Patricia A. Kasting, our ever-resourceful law librarian. An earlier version of this article was presented to the AFCC Think Tank on Closing the Gap: Research, Practice, Policy and Shared Parenting in January 2013 and published as J. Herbie DiFonzo, Kristin Pezzuti, Nicole Guliano, and Diana Rivkin, Joint Custody Laws and Policies in the Fifty States, AFCC eNEWS, Vol. 8, No. 2 (Feb. 2013), available at https://afcc.networkats.com/uploads/ES/2013/02\%202013\%20Feb/2013-02-Feb-Joint-Custody -Memorandum.pdf.

2. Linda D. Elrod and Milfred D. Dale, Paradigm Shifts and Pendulum Swings in Child Custody: The Interests of Children in the Balance, 42 Fam. L.Q. 381 (2008).

3. See I William BlacKstone, COMMENTARIES *452 (observing that the father maintained ultimate authority over his children in Roman law). 
4. See Michael Grossberg, Governing the HeARTh: LaW and The FAmily in NineteEnth-CENTURY AmERICA 235 (1985) (observing that the father's entitlement was " $[\mathrm{m}]$ oored in the medieval equation of legal rights with property ownership.”).

5. See Ex parte Devine, 398 So.2d 685, 688 (Ala. 1981) ("The husband was considered the head or master of his family, and, as such, responsible for the care, maintenance, education and religious training of his children. By virtue of these responsibilities, the husband was given a corresponding entitlement to the benefits of his children, i.e., their services and association.").

6. See Jamil S. Zainaldin, The Emergence of a Modern American Family Law: Child Custody, Adoption, and the Courts, 1796-1851, 73 Nw. U. L. REV. 1038, 1052-59 (1979) (describing how the common law's strict paternal entitlement began to give way to discretionary judicial consideration of child welfare in early nineteenth century cases).

7. Hines v. Hines, 185 N.W. 91, 92 (Iowa 1921); see Mercein v. People, ex rel. Barry, 25 Wend. 64, 106 (N.Y. 1840) (awarding custody of a child to the mother because "the law of nature has given to her an attachment for her infant offspring which no other relative will be likely to possess in an equal degree"); Fritz v. Fritz, 148 N.W.2d 392, 398 (Iowa 1967) (noting that the tender years presumption is based on "the premise that the fundamental attributes of gentleness, moral stability, honesty, and a sense of value in the field of education, ambition, and achievement are somehow stronger and more pronounced in mothers than in fathers").

8. See, e.g., In re Bowen's Marriage, 219 N.W.2d 683, 688 (Iowa 1974) (“Modern redefinition and adjustment of traditional parental roles has greatly diluted the strength of the [gender link.]".

9. Id.; see also Bazemore v. Davis, 394 A.2d 1377, 1381 (D.C. 1978) ("Such an assumption ... fails to take into account the realities of the divorced or single mother, who must assume the obligations of both parents, and is often not at home caring for the child but out working.").

10. Bazemore v. Davis, 394 A.2d 1377, 1381 (D.C. 1978).

11. Alan D. Scheinkman, Practice Commentaries, N.Y. DOM. REL. LAW $§ 240$ (McKinney), at C240:9.

12. Ross v. Ross, 339 A.2d 447, 448 (D.C. 1975); see also Bernardo Cuadra, Material and Joint Custody Presumptions for Unmarried Parents, 32 W. NEW ENG. L. REV. 599, 605 (2010) (citing studies showing that trial courts continue to apply the tender-years presumption sub rosa); RichARD A. WARSHAK, THE CUSTODY REVOLUTION: THE FATHER FACTOR AND THE MOTHERHOOD MYstiQue 32 (1992) ("The legacy of the tender-years presumption has continued to influence custody decisions, so that the best-interest standard, despite its literal meaning, has come to be interpreted primarily as a justification for the mother's preferential claim in custody disputes.").

13. See, e.g., High v. High, 697 S.E.2d 690, 700 (S.C. App. 2010).

14. See, e.g., In re Marriage of Robison, 53 P.3d 1279, 1283 (Mont. 2002).

15. John DeWitt Gregory et AL., Understanding FamiLY LAW $\left(4^{\text {th }}\right.$ ed. 2013) at $\S 11.03$ [3]. See Joan B. Kelly, The Determination of Child Custody, 4 The Future of Children 130-131 (1994) (noting that the primary caretaker presumption penalizes men for being the principal wage earner during the marriage and ignores "the most important emotional and interactive behaviors promoting children's development and psychological, social, and academic adjustment, such as love, acceptance, respect, encouragement of autonomy, learning, and self-esteem, moral guidance, and absence of abusive interactions ..."); see also Rebecca E. Hatch and Leann Michael, Gender Bias as Factor in Child Custody Cases, 131 AM. JUR. PROOF OF FACTS 3d 457, 1 (2013) (observing that "where a Mother is the one to provide for the child's care and the Father takes on the career role, a judge may be inclined to maintain this relationship in order to keep the environment stable for the child").

16. See, e.g., MINN. STAT. ANN. $§ 518.17$ (West) ("The primary caretaker factor may not be used as a presumption in determining the best interests of the child."); Arthur v. Arthur, 2013 WL 2150858 (Ga. 2013) (holding that the trial court's finding that mother had been the children's primary caretaker was sufficient to support its award of primary physical custody to her); Gordon v. Richards, 959 N.Y.S.2d 562, 563 (N.Y. App. 2013) (upholding the trial court's award of primary physical custody to the mother on finding that she had been the primary caretaker for most of the child's life and was best able to provide stability for the child); Evans v. Evans, 610 S.E.2d 264, 267 (N.C. 2005) (affirming court's order giving father primary residence in part because he "has been a primary source of care and tuition for the minor children since their birth."); MINN. STAT. ANN. § 518.17 (listing "the child's primary caretaker" as a relevant factor in ascertaining the best interests of the child).

17. ARIZ. REV. STAT. ANN. § 14-846(B) (1956) (enacted as REV. STAT. ARIZ. 1913, Civil Code, para. 1122; repealed by 1973 Ariz. Sess. Laws, ch. 75, § 3).

18. Ex parte Devine, 398 So.2d 686, 691 (Ala. 1981).

19. McCann v. McCann, 173 A.7, 9 (Md. 1934).

20. Martin v. Martin, 132 S.W.2d 426, 428 (Tex. Civ. App. 1939). See id. ("It is readily apparent that such practices are calculated to arouse serious emotional conflicts in the mind of the child. ..."); McLemore v. McLemore, 346 S.W.2d 722, 724 (Ky. App. 1961) (quoting Towles v. Towles, 195 S.W. 437, 438 (Ky. App. 1917)) (Divided custody "would be greatly to the detriment of the children, because it would give them no fixed or permanent home, but rather keep them unsettled and on the move. Nothing can be more demoralizing to a home or destructive to good citizenship ...").

21. Logan v. Logan, 176 S.W.2d 601, 603 (Tenn. App. 1943). Occasionally, some appellate courts in the early-to-mid $20^{\text {th }}$ century affirmed decisions awarding joint or divided custody, even while noting the general disapproval of these arrangements. See, e.g., State ex rel. Sprague v. Butcher, 270 SW2d 565 (Tenn. App. 1953); McGarraugh v. McGarraugh, 177 S.W.2d 296 (Tex. Civ. App. 1943); Ex parte Winn, 63 P.2d 198, 202 (Ariz. 1936); Com. v. Strickland, 27 Pa. Super. 309 (1905).

22. Linda ElRod, CHILD CUSTODY PRAC. \& PROC. § 1:8. Joint custody. 
23. N.C. GEN. STAT. § 50-13.2(b) (enacted in 1975).

24. Elizabeth Scott and Andre Derdeyn, Rethinking Joint Custody, 45 Ohio State L.J. 455, 456 n.3 (1984). As of 2012, forty-seven states and the District of Columbia have statutes authorizing joint legal and/or physical custody. Dorothy R. Fait et al., The Merits and Problems with Presumptions for Joint Custody, 45 MD. BAR J. 12, 14 (Feb. 2012).

25. Taylor v. Taylor, 508 A.2d 964, 970 (Md. 1986). See also Beck v. Beck, 482 A.2d 63 (N.J. 1981); Daniel v. Daniel, 238 S.E.2d 108 (Ga. 1977).

26. See Chart 2: Custody Criteria, 46 FAM. L.Q. 524-527 (2013), at http://www.americanbar.org/content/dam/aba/ publications/family_law_quarterly/vol46/4win13_chart2_custody.authcheckdam.pdf.

27. Taylor v. Taylor, supra, 508 A.2d at 970. See id. at 971 ("Rarely, if ever, should joint legal custody be awarded in the absence of a record of mature conduct on the part of the parents evidencing an ability to effectively communicate with each other concerning the best interest of the child, and then only when it is possible to make a finding of a strong potential for such conduct in the future.").

28. Braiman v. Braiman, 378 N.E.2d 1019, 1021 (N.Y. 1978). See also In re Marriage of M.A., 2004 WL 1048194 (Mo. App. 2004) ("A commonality of beliefs concerning parental decisions and the parties' ability to function as a parental unit in making those decisions are important considerations in determining whether joint legal custody is in the child's best interests."); Farrell v. Farrell, 819 P.2d 896, 899 (Alaska 1991) (noting that "joint legal custody is only appropriate when the parents can cooperate and communicate in the child's best interest"); ELROD, supra note 22, at $\S 1: 8$ ("Recent studies indicate there are as many postdivorce problems with joint custody as with sole custody if parents continue to create a hostile environment."). By contrast, divorcing parents who together request joint custody should be entitled to carry out that custodial arrangement. In 2012, the Illinois Supreme Court suggested that "the right of fit parents to decide what is in their children's best interests is of constitutional magnitude.” In re Marriage of Coulter \& Trinidad, 976 N.E.2d 337, 342 (Ill. 2012).

29. Wendy Wang, Parents' Time with Kids More Rewarding Than Paid Work - and More Exhausting, Pew Research Social \& Demographic Trends, Oct. 8, 2013, at http://www.pewsocialtrends.org/2013/10/08/parents-time-with-kids-more-rewarding -than-paid-work-and-more-exhausting/.

30. Id.

31. Marsha Kline Pruett \& J. Herbie DiFonzo, Closing the Gap: Research, Policy, Practice and Shared Parenting, 52 FAM. CT. REV. 152 (2014).

32. Fiona Kelly, Enforcing A Parent/Child Relationship at All Cost? Supervised Access Orders in the Canadian Courts, 49 Osgoode Hall L.J. 277, 278 (2011); see also Patrick Parkinson, When is Parenthood Dissoluble?, 26 B.Y.U. J. PUB. L. 147, 156-157 (2012) (describing legislative reforms in Australia to encourage shared parenting).

33. New Zealand Care of Children Act 2004, Sec. 5, at http://www.legislation.govt.nz/act/public/2004/0090/latest/ DLM317241.html (emphasizing the child's need for "continuing relationships with both of his or her parents").

34. Taylor v. Taylor, supra, 508 A.2d at 966.

35. See, e.g., O’Brien v. O’Brien, 704 So. 2d 933, 935 (La. App. 1997) ("Each child custody case must be viewed in light of its unique facts and circumstances with the principal goal of reaching a decision that embodies the best interest of the child."); New Zealand Care of Children Act 2004, Sec. 4 ("The welfare and best interests of the child must be the first and paramount consideration. ...") .

36. See, e.g., LA. CIV. CODE ANN. art. 134 (setting out 12 factors for the court to consider in determining the best interests of the child).

37. The relevant South Dakota statute commands only consideration of the child's "temporal, mental, and moral welfare." S.D. CODIFIED LAWS § 25-5-10. The state supreme court fleshed out those five words into a substantial listing of six multi-faceted factors. Fuerstenberg v. Fuerstenberg, 591 N.W.2d 798, 807 (S.D. 1999).

38. Alan D. Scheinkman, Practice Commentaries, N.Y. DOM. REL. LAW $§ 240$ (McKinney). New York's custody statute runs against the grain of most statutes in supplying practically no guidance, noting only that the court "shall enter orders for custody ... as, in the court's discretion, justice requires, having regard to the circumstances of the case and of the respective parties and to the best interests of the child. .." N.Y. DOM. REL. LAW $\S 240(1)$ (a). The statute specifies only certain violence and abuse factors as considerations for custody. If allegations of domestic violence "are proven by a preponderance of the evidence, the court must consider the effect of such domestic violence upon the best interests of the child. ..." Id. The court "shall not place a child in the custody of a parent who presents a substantial risk of harm to that child. ..." Id. Nor may the court award custody to a person convicted of the murder of a parent, legal custodian or guardian, or sibling of the child at issue in the proceeding. Id. at 1-c.(a). The New York statute provides no distinction between legal and physical custody.

39. See, e.g., IND. CODE ANN. § 31-14-13-2 (West) (listing eight factors); Fitzsimmons v. Fitzsimmons, 722 P.2d 671 , 675 (New Mex. App. 1986) (noting that the child custody statute "does not mandate that the court give greater or lesser weight to any specific factor. That is a matter reserved to the trial court's discretion. It is the trial judge who hears all the evidence, who observes the demeanor of the parties and their witnesses and who is in the best position to exercise his sound judgment.").

40. See, e.g., Benal v. Benal, 22 So.2d 369, 372-377 (Ms. App. 2009) (identifying and discussing the 11 factors set out by the state supreme court in Albright v. Albright, 437 So.2d 1003 (Ms. 1983)).

41. The Texas statute reflects a common theme in declaring that the "public policy of this state" consists of "assur[ing] that children will have frequent and continuing contact with parents who have shown the ability to act in the best interest of the child; [] provid[ing] a safe, stable, and nonviolent environment for the child; and [] encourag[ing] parents to share in the rights and 
duties of raising their child after the parents have separated or dissolved their marriage." TEX. FAM. CODE ANN. § 153.001 (West). In Canada, the Divorce Act provides both that the court must consider "only the best interests of the child," but that in doing so the court must adhere to "the principle that a child of the marriage should have as much contact with each spouse as is consistent with the best interests of the child. ...” Divorce Act [Canada], R.S.C., 1985, c.3 (2 ${ }^{\text {nd }}$ Supp.).

42. ARIZ. REV. STAT. ANN. § 25-401 (added by Laws 2012, Ch. 309, § 4).

43. Id. This section also provides that during the scheduled parenting time each parent "is responsible for providing the child with food, clothing and shelter and may make routine decisions concerning the child's care." Id.

44. Id., § 25-403.01.

45. Id., § 25-403.

46. Id., § 25-403.01.

47. See ELROD, supra note 22, at § 5:8. Statutory criteria; Fait et al., supra note 24, at, 14.

48. New York, North Dakota, and Rhode Island do not have statutes providing for joint custody, but each state permits these orders through case law. See Braiman v. Braiman, 378 N.E.2d 1019 (N.Y. 1978); Fonder v. Fonder, 823 N.W.2d 504 (N.D. 2012 ); and Murphy v. Murphy, 714 A.2d 576 (R.I. 1998).

49. See Minnesota Joint Physical Child Custody Presumption Study Group Report (Jan. 14, 2009), App. A, at 29-25 (survey of state-by-state presumptions as of 2008), at http://www.leg.state.mn.us/docs/2009/mandated/090065.pdf.

50. IOWA CODE ANN. § 598.41 (West).

51. 2013 Arkansas Laws Act 1156 (S.B. 901) (amending ARK. CODE ANN. § 9-13-101(a)) (emphasis omitted). The new legislation also provided that "custody shall be awarded in such a way so as to assure the frequent and continuing contact of the child with both parents" consistent with the child's best interest, including the provision favoring an award of joint custody. Id.

52. Bailey v. Bailey, 244 S.W.3d 712, 714 (Ark. App. 2006); see Aaron v. Aaron, 305 S.W.2d 550, 552 (Ark. 1957) ("Divided custody of a minor child is not favored, unless circumstances clearly warrant such action.").

53. Kamal v. Imroz, 759 N.W.2d 914, 918 (Neb. 2009); see also McIver v. McIver, 2013 WL 5434646 (Neb. App. Oct. 1, 2013) ("Nebraska has not yet recognized a presumption in favor of joint custody, and joint custody remains disfavored to the extent that if both parties do not agree, the court can award joint custody only if it holds a hearing and makes the required finding.").

54. See, e.g., D.M.P.C.P. v. T.J.C., Jr., 2012 WL 6554383 (Ala. App. 2012); Arndt v. Arndt, 100 A.D.3d 879, 954 N.Y.S.2d 196 (N.Y. App. 2012); Lewis v. Lewis, 734 S.E.2d 322 (S.C. App. 2012); Earley v. Earley, 2012 WL 4862551 (Ohio Ap. 2012 ); Shinall v. Carter, 2012 IL App (3d) 110302 (Ill. App. 2012); Pena v. Stoddard, 2011 WL 704324 (Tex. App. 2011). Of course, the lack of communication must rise to the level of impeding joint parenting. See Nguyen v. Le, 960 So.2d 261, 266 (La. App. 2007) (affirming a joint custody ruling, observing that while the parties had "a lack of communication with each other, ... neither party related any specific instance where they disagreed regarding parenting decisions").

55. MO. ANN. STAT. § 452.375(5)(1) (West).

56. ALA. CODE $\S 30-3-152$ (b); cf. id., § 30-3-152(b) (providing that joint custody is presumed to be in the best interests of the child if the parents both request it); see also IOWA CODE ANN. $§ 598.41$ (West) (directing the court to "consider granting joint custody in cases where the parents do not agree to joint custody" on the application "of either parent").

57. Fountain v. Waguespack, 639 So.2d 882, 887 (La. App. 1994) (characterizing LA. Civ. CodE ANN. art. 132).

58. See, e.g., Elrod \& Dale, supra note 2, at 399 (noting that when joint custody was ordered over one party's objection, "the rate of relitigation is roughly the same as when a parent has sole custody").

59. Rosenfeld v. Rosenfeld, 529 N.W.2d 724, 726 (Minn. Ct. App. 1995).

60. Meyer v. Anderson, 2002 WL 1251449 (Ohio App. 2002).

61. See, e.g., South Dakota Codified Laws § 25-5-7.1 ("In any custody dispute between parents, the court may order joint legal custody so that both parents retain full parental rights and responsibilities with respect to their child and so that both parents must confer on, and participate in, major decisions affecting the welfare of the child.”).

62. VA. CODE ANN. § 20-124.2B.

63. Peterson v. Swarthout, 214 P.3d 332, 336n.6 (Alaska 2009).

64. Id. (noting that while joint legal custody is preferred, it "is only appropriate when the parents can cooperate and communicate in the child's best interest.”) (quoting Farrell v. Farrell, 819 P.2d 896, 899 (Alaska 1991)).

65. KAN. STAT. ANN. § 23-3206 (West).

66. GA. CODE ANN. § 19-9-3(a)(1).

67. Id. $\S 19-9-3(\mathrm{~d})$.

68. Willis v. Willis, 707 S.E.2d 344, 347 (Ga. 2011).

69. HAW. REV. STAT. § 571-46(a)(1) (West); see also IND. CODE § 31-17-2-13 ("The court may award legal custody of a child jointly if the court finds that an award of joint legal custody would be in the best interest of the child."); KY. REV. STAT. ANN. § 403.270 (5) ("The court may grant joint custody to the child's parents ... if it is in the best interest of the child.”). In the case of Marriage of Gerchak, 2007 WL 5471744 (Ariz. App. 2007), the appellate court explicitly rejected a party's assertion that there was "an unstated presumption in the judicial system" that joint custody is preferred. $I d$. at *3. The court affirmed that Arizona law called upon the court to determine the appropriate custodial arrangement exclusively upon the best interests of the child. Id.; ARIZ. REV. STAT. § 25-403.The Maryland Court of Appeals carefully articulated its rationale for refusing to adopt any custody preferences:Formula or computer solutions in child custody matters are impossible because of the unique character of each case, and the subjective nature of the evaluations and decisions that must be 
made. At best we can discuss the major factors that should be considered in determining whether joint custody is appropriate, but in doing so we recognize that none has talismanic qualities, and that no single list of criteria will satisfy the demands of every case ... We emphasize that in any child custody case, the paramount concern is the best interest of the child. Taylor v. Taylor, 508 A.2d 964, 970 (Md. 1986).

70. ARIZ. REV. STAT. § 25-403.01(A) (Ariz. Laws 2012, Ch. 309 (effective Jan. 1, 2013)).

71. Id., § 25-403.01(B); see § 25-403(A) (listing the eleven factors); § 25-403.01(B) (listing the four additional factors).

72. Id., § 25-403.02(B).

73. Id., § 25-403.01(D). The court need not comply with this directive if after a hearing it finds "that parenting time would endanger the child's physical, mental, moral or emotional health." Id.

74. Word v. Remick, 58 S.W.3d 422, 426 (Ark. App. 2001) (“Joint custody or equally divided custody of minor children is not favored in Arkansas unless circumstances clearly warrant such action.”).

75. See VT. STAT. AnN. tit. $15 \S 665$ (a) ("When the parents cannot agree to divide or share parental rights and responsibilities, the court shall award parental rights and responsibilities primarily or solely to one parent."; Cabot v. Cabot, 697 A.2d 644, 649 (Vt. 1997) ("The meaning of $\S 665$ (a) is plain: where the parents cannot agree, the court must award primary (or sole) parental rights and responsibilities to one parent.").

76. In re Marriage of Dobey, 258 Ill.App.3d 874, 876 (1994). Maryland's highest court has also emphasized the need for evidence of both present harmonious contact between the parents and a basis for believing the pattern has been set for further cooperation: "Rarely, if ever, should joint legal custody be awarded in the absence of a record of mature conduct on the part of the parents evidencing an ability to effectively communicate with each other concerning the best interest of the child, and then only when it is possible to make a finding of a strong potential for such conduct in the future." Taylor v. Taylor, 508 A.2d 964, 971 (Md. 1986). Resolving disputes between joint legal custodians has led more than one appellate judge to opine that "[1]ike so many theories which have a noble purpose, [joint legal custody] often prove[s] to be unworkable when tested in a practical world." Matter of Marriage of Debenham, 896 P.2d 1098, 1099-1100 (Kan. App. 1995) (quoting Burchell v. Burchell, 684 S.W.2d 296, 301 (Ky. App. 1984) (Gudgel, J., concurring and dissenting)). The Debenham court reluctantly affirmed the trial judge's resolution of a school placement issue, noting the likelihood that "neither party will find much satisfaction with our decision" and that the parents "may well litigate the school issue on a yearly basis." Debenham, supra, 896 P.2d at 1101. The appellate court blamed the legislature for its discomfort: "[O]ur legislature has declared joint custody and equal decisional rights as the public policy of this state. Under such mandate, courts are ill-equipped to decide these questions; but the courts must do so as best they can." Id.

77. Braiman v. Braiman, 378 N.E.2d 1019 (N.Y. 1978); see Timothy Tippins, 3 New York Matrimonial Law and Practice § 21:3. Braiman rule (describing the Braiman case as the "premier fount of New York's decisional law relative to joint custody ...").

78. Braiman v. Braiman, supra, 378 N.E.2d at 1021.

79. See, e.g., Martinez v. Hyatt, 86 A.D.3d 571, 927 N.Y.S.2d 375 (N.Y. App. 2011) (quoting Braiman v. Braiman, supra); Gorniok v. Zeledon-Mussio, 82 A.D.3d 767, 918 N.Y.S.2d 516 (N.Y. App. 2011) (same); Fiorelli v. Fiorelli, 34 A.D.3d 1216, 824 N.Y.S.2d 695 (N.Y. App. 2006) (same).

80. TAMmy E. HinshaW \& Judy E. Zelin, 19B CARMOdY-WAit 2D § 118A:85. Joint custody. See Robert Emery, Joint Physical Custody, Psychology Today, May 18, 2009, at http://www.psychologytoday.com/blog/divorced-children/200905/joint -physical-custody (observing that "joint physical custody is the best and the worst arrangement for children. It's the best when parents can cooperate enough to make joint physical custody work for children. It's the worst when joint physical custody leaves children in the middle of a war zone.").

81. McCarty v. McCarty, 807 A.2d 1211, 1213 (Md. Spec. App. 2002) (quoting Taylor v. Taylor, 508 A.2d 964, 967 (Md. 1986)).

82. See Mason v. Coleman, 850 N.E.2d 513, 518 (Mass. 2006) ("Shared physical custody necessitates ongoing joint scheduling and provision for supervision and transportation of children between homes, schools, and youth activities.").

83. McCarty v. McCarty, supra, 807 A.2d at 1213 (quoting Taylor v. Taylor, supra 508 A.2d at 967).

84. ARIZ. REV. STAT. § 25-403.02(E). See also CONN. GEN. STAT. § 46b-56a (West 2005) (noting that "the court may award joint legal custody without awarding joint physical custody where the parents have agreed to merely joint legal custody."); HAW. REV. STAT. § 571-46.1(b) (providing that the court's order "may award joint legal custody without awarding joint physical custody.”); IND. CODE $§ 31-17-2-14$ (“An award of joint legal custody . . . does not require an equal division of physical custody of the child.").

85. See Bell v. Bell, 794 P.2d 97, 99 (Alaska 1990) ("While actual physical custody may not be practical or appropriate in all cases, it is the intent of the legislature that both parents have the opportunity to guide and nurture their child and to meet the needs of the child on an equal footing beyond the considerations of support or actual custody.") (quoting An Act Relating to Child Custody, ch. $88 \S 1$ (a), SLA 1982). The actual prevalence of joint physical custody is hard to estimate. Two decades ago, a California study found joint legal custody ( $79 \%$ of cases) much more common that joint physical custody (19.6\% of cases). Significantly, the study also found that a substantial shift took place in many joint physical custody cases. Within three years of the court order, $45 \%$ of the joint physical custody arrangements had become de facto sole custody situations, with children living with their mothers. Eleanor Maccoby \& Robert MnOokin, Dividing The Child: Social AND Legal Dilemmas of Custody (Harvard University Press 1992). A 2009 Washington State study found that " 46 percent of children of divorce, statewide, are ordered to spend a minimum of 35 percent parenting time with their biological fathers." Bill 
Harrington, Giving Parents Equal Parenting Time by Law, Seattle Times, Feb. 25, 2009, at http://seattletimes.com/html/opinion/ 2008786615_opinb26harrington.html (discussing the Residential Time Summary Report prepared by the state Office of the Administrator for the Courts).

86. Mo. Rev. STAT. § 452.375(1)(3) (2011); see, e.g., 750 ILl. COMP. STAT. 750 ILCS 5/602.1(d) ("Nothing within this section shall imply or presume that joint custody shall necessarily mean equal parenting time."); Squires v. Squires, 854 S.W.2d 765, 764 (Ky. 1993) ("Equal time residing with each parent is not required, but a flexible division of physical custody of the children is necessary.").

87. MO. REV. STAT. § 452.375(1)(3) (2011).

88. MASS. GEN. LAWS ANN. ch. 208, § 31 (West); see also N.J. REV. STAT. § 9:2-4 (declaring "the public policy of this State to assure minor children of frequent and continuing contact with both parents after the parents have separated or dissolved their marriage and that it is in the public interest to encourage parents to share the rights and responsibilities of child rearing in order to effect this policy").

89. TENN. CODE ANN. § 36-6-106(a). Wisconsin has a similar statute which call for the court to "set a placement schedule that allows the child to have regularly occurring, meaningful periods of physical placement with each parent and that maximizes the amount of time the child may spend with each parent, taking into account geographic separation and accommodations for different households.” WiS. STAT. § 767.41(4)(a)(2).

90. CAL. FAM. CODE $\S \S 3002,3080$ (West 1993).

91. Id., § 3011.

92. Id., § 3004. Another provision gives the court the power to grant joint legal custody without joint physical custody. Id., $\S 3085$.

93. IDAHO CODE ANN. § 32-717B(4).

94. Id., § 32-717B(2)

95. Id., § 32-717B(4); see also D.C. CODE $§ 16-914$ (providing "a rebuttable presumption that joint custody is in the best interest of the child . .." but apparently subsuming it under the authority of the court to "issue an order that provides for frequent and continuing contact between each parent and the minor child or children and for the sharing of responsibilities of child-rearing and encouraging the love, affection, and contact between the minor child or children and the parents").

96. LA. REV. STAT. ANN. § 9:335(A)(2)(b).

97. Brewer v. Brewer, 895 So.2d 745, 750 (La. App. 2005).

98. GA. CODE ANN., § 19-9-6(6) (West 2011).

99. NEV. REV. STAT. ANN. § 125.460 (West).

100. Rivero v. Rivero, 216 P.3d 213, 219 (Nev. 2009). See also OKLA. STAT. ANN. tit. 43, § 110.1 (West) (unless the court finds that shared parenting would be detrimental to the child, it must provide "substantially equal access to the minor children to both parents at a temporary order hearing.”); Miller v. Miller, 568 S.E.2d 914, 918 (N.C. App. 2002) (for child support calculation purposes, the term joint custody applies where "each parent has custody for more than one-third of the year ...").

101. UTAH CODE ANN. § 30-3-10.1 (West).

102. Id., § 30-3-32.

103. Id., § 30-3-35 and 30-3-35.5, respectively.

104. Id., § 30-3-34(2).

105. MINN. STAT. § 518.175(1)(e).

106. Id.

107. AMERICAN LAW INSTITUTE, PRINCIPLES OF THE LAW OF FAMILY DisSOLUTION $\S 2.08$ (2002) (proposing that, in the absence of parental agreement, "the court should allocate custodial responsibility so that the proportion of custodial time the child spends with each parent approximates the proportion of time each parent spent performing caretaking functions for the child prior to the parents' separation or, if the parents never lived together, before the filing of the action ....).

108. W.VA. CODE $§ 48-9-206(a)$.

109. Id., § 48-9-206(a)(1-8).

110. TeX. FAm. Code ANN. § 153.134(b)(1).

111. Id., § 153.134(b)(2) \& (b)(4).

112. Id., § 153.002 .

113. IDAHO CODE ANN. § 32-717B (West).

114. Id.

115. Id. In Idaho, as in some other states with a joint custody presumption, a court awarding sole custody must make specific findings describing why joint custody is inappropriate. IDAHO CODE ANN. § 32-717B; see Roeh v. Roeh, 746 P.2d 1016, 1020 (Ida. App. 1987) (noting that "if a court determines to award either physical or legal custody solely to one parent, the court is required to state in its decision the reasons why the award is not for joint custody."). In that case, the appellate court stressed the importance of a high level of specificity; merely alluding to one party's unfitness or including facts that only implied the court's reasoning was held insufficient to overcome the presumption. Roeh v. Roeh, supra, 746 P.2d at $1018-21$.

116. CAL. FAM. CODE $\S 3002,3020$ (West). Joint legal custody is defined conventionally, with both parents sharing "the right and the responsibility to make the decisions relating to the health, education, and welfare of a child." Id., § 3003 .

117. Id., $\S 3080$. The presumption is also subject to the statute detailing the best interest considerations. See $\S \S 3011,3080$.

118. Id., $\S 3004$. This provision is also subject to the best interest statute (Id., § 3011). 
119. In almost identical terms, the Florida Legislature pronounced "the public policy of this state that each minor child has frequent and continuing contact with both parents after the parents separate or the marriage of the parties is dissolved and to encourage parents to share the rights and responsibilities, and joys, of childrearing." FLA. STAT. ANN. $\S 61.13$ (West). Accordingly, courts are directed to "order that the parental responsibility for a minor child be shared by both parents unless the court finds that shared parental responsibility would be detrimental to the child." Id. But there is no presumption "for or against any specific time-sharing schedule when creating or modifying the parenting plan of the child." Id.

120. See ALA. CODE $\S 30-3-152$ (c) ("If both parents request joint custody, the presumption is that joint custody is in the best interest of the child."); CAL. FAM. CODE $\S 3080$ (West 1993) ("There is a presumption, affecting the burden of proof, that joint custody is in the best interest of a minor child ... where the parents have agreed to joint custody or so agree in open court at a hearing for the purpose of determining the custody of the minor child."); CONN. GEN. STAT. § 46b-56a(b) ("There shall be a presumption, affecting the burden of proof, that joint custody is in the best interests of a minor child where the parents have agreed to an award of joint custody or so agree in open court."); N.M. STAT. ANN. § 40-4-9.1(D) (“In any case in which the parents agree to a form of custody, the court should award custody consistent with the agreement unless the court determines that such agreement is not in the best interests of the child.") The New Hampshire custody statute contains a presumption "that joint decision-making responsibility is in the best interest of minor children" which may be triggered either by mutual agreement or by the request of "either parent." N.H. REV. STAT. ANN. § 461-A:5(I-II). In the latter case, joint custody may be awarded in the court's discretion, and the court may appoint a guardian ad litem to assist in this determination. In either case, should the court refuse to order joint custody it "shall state in its decision the reasons for the denial." Id.

121. TENN. CODE ANN. §36-6-101(a)(2)(A)(i).

122. See, e.g., CONN. GEN. STAT. § 46b-56a(b); Tennessee Code § 36-6-101(a)(2)(A)(i).

123. Darvarmanesh v. Gharacholou, 2005 WL 1684050, at*7 (Tenn. App. 2005) (quoting Dodd v. Dodd, 737 S.W.2d 286, 290 (Tenn. App. 1987)).

124. Id. (quoting Garner v. Garner, 773 S.W.2d 245, 248 (Tenn. App. 1989) (Koch, J., dissenting)).

125. W. VA. CODE ANN. § 48-9-207(b) (West). This type of presumption aligns with West Virginia's approximation rule for allocating custodial responsibility: "[T]he court shall allocate custodial responsibility so that the proportion of custodial time the child spends with each parent approximates the proportion of time each parent spent performing caretaking functions for the child prior to the parents' separation ..."W. VA. CODE ANN. § 48-9-206 (West).

126. W. VA. CODE $§ 48-9-207$ (b) (West).

127. NEB. REV. STAT. § 42-364(3)(b). In 2012, the South Carolina Legislature amended its custody statutes to provide that "[i]f custody is contested or if either parent seeks an award of joint custody, the court shall consider all custody options, including, but not limited to, joint custody ..." S.C. CODE ANN. § 63-15-230(C) (2012).

128. NEB. ReV. StAT. § 42-364(3)(b).

129. See Kay v. Ludwig, 686 N.W.2d 619, 628-630 (Neb. App. 2004) (describing the sequence of court decision and legislative enactment).

130. Id., 686 N.W.2d at 629. In 2007, the Nebraska Supreme Court further narrowed the scope of a trial court's ability to order joint physical custody in cases in which neither parent requested it. Zahl v. Zahl, 736 N.W.2d 365 (Neb. 2007).

131. See, e.g., TENN. CoDE ANN., § 36-6-101(a)(2)(A)(i) (“[N]either a preference nor a presumption for or against joint legal custody, joint physical custody or sole custody is established. ...").

132. See, e.g., WYO. STAT. ANN., § 20-2-201(a) ("[T] he court may make by decree or order any disposition of the children that appears most expedient and in the best interests of the children."); id., § 20-2-201(d) "Custody shall be crafted to promote the best interests of the children, and may include any combination of joint, shared or sole custody."

133. These include Florida, Idaho, Louisiana, New Mexico, Texas, Washington, D.C., Wisconsin, and Utah. For example, the Idaho statute provides that "absent a preponderance of the evidence to the contrary, there shall be a presumption that joint custody is in the best interests of a minor child or children." IDAHO CODE ANN. § 32-717B(4). The Florida statute similarly provides that the court "shall order that the parental responsibility for a minor child be shared by both parents unless the court finds that shared parental responsibility would be detrimental to the child." FLA. STAT. § 61.13(2)(c)(2) (2009). A recent Florida appellate case has held, however, that even with this statutory presumption and with a signed parental agreement, a trial court should have conducted its own best interests analysis prior to entry of a joint custody order. Sparks v. Sparks, 75 So.3d 861 (Fla. App. 2011). Note that a parent's domestic violence offense or history of domestic violence will frequently serve to rebut the presumption. Jurisdictions with these provisions include Idaho, Texas, Utah, Washington, D.C., West Virginia, and Wisconsin. The Idaho statute contains a presumption "that joint custody is not in the best interests of a minor child if one (1) of the parents is found by the court to be a habitual perpetrator of domestic violence.” IDAHO CODE ANN. § 32-717B(5).

134. N.M. STAT. ANN. § 40-4-9.1(A).

135. Id., § 40-4-9.1(B).

136. Id., § 40-4-9.1(C).

137. Id., § 40-4-9.1(E).

138. Id., § 40-4-9.1(F).

139. Id.

140. Id.

141. Id., §§ 40-4-9.1(J)(1); 40-4-9.1(L)(4).

142. Id., § 40-4-9.1(J)(2).

143. Id., § 40-4-9.1(J)(3). 
144. Id., § 40-4-9.1(J)(4)(a-e).

145. Id.

146. Id.

147. Black's Law Dictionary 1223 (8th ed. 2004).

148. Fed. R. Evid. 301.

149. Unif. R. Evid. 302(a). See Leo H. Winery, The Uniform Rules of Evidence (1999): Presumptions and Their Effect, 54 OKLA. L. REV. 553, 556-557 (2001) (elaborating on the differences between the two types of presumptions).

150. Black's Law Dictionary 1224 (8th ed. 2004).

151. Fait et al., supra note 24 , at 15 .

152. Id. at 15-16.

153. See, e.g., Ala. CODE $\S 30-3-152(\mathrm{C})$; NEV. REV. STAT. $§ 125.490$.

154. See Robert E. Emery \& Kimberly C. Emery, Should Courts or Parents Make Child-Rearing Decisions?: Married Parents as a Paradigm for Parents Who Live Apart, 43 WAKE FOREST L. REV. 365 (2008) (arguing that the authority of the courts to intervene in the decision making of never married, divorced and separated parents is too broad; the better approach is a hands off doctrine).

155. Scott \& Derdeyn, supra note 24, at 457. Their article was published in 1984.

156. Id.; see Nancy Ver Steegh \& Dianna Gould-Saltman, Joint Legal Custody Presumptions: A Troubling Legal Shortcut, 52 FAM. CT. REV. 263 (2014).

157. Margaret F. Brinig, Penalty Defaults in Family Law: The Case of Child Custody, 33 FLA. ST. U. L. REV. 779, 781-82 (2006) (footnotes omitted).

158. See, e.g., WASH. REV. CODE ANN. § 26.09.191(1) (West) (declaring that "mutual decision-making" shall not be required if the court has found that a parent has engaged in "a history of acts of domestic violence . . or an assault or sexual assault which causes grievous bodily harm or the fear of such harm.”); IDAHO CODE ANN. § 32-717B(5) (2000) (presumption against joint custody if one of parents is found to be a habitual perpetrator of domestic violence); MINN. STAT. ANN. $\S 518.17$, sub. 2 (2000) (rebuttable presumption that joint legal or physical custody is not in the best interests of the child if domestic abuse has occurred); FLA. STAT. ANN. § 61.13(2)(b)(2) (2000) (same). In 1990, the U.S. Congress passed a concurrent resolution that "for purposes of determining child custody, credible evidence of physical abuse of a spouse should create a statutory presumption that it is detrimental to the child to be placed in the custody of the abusive spouse. H. CON. RES. 172 (1990). See also Judith G. Greenberg, Domestic Violence and the Danger of Joint Custody Presumptions, 25 N. ILL. U. L. REV. 403, 415 (2005) ("Not surprisingly, there is tremendous agreement among commentators that joint custody, legal or physical, is not desirable in families in which there is a history of domestic violence.").

159. See Leslie Joan Harris, Failure to Protect from Exposure to Domestic Violence in Private Custody Contests, 44 FAM. L.Q. 169, 171-72 (2010) ("Laws providing that courts must consider evidence that one parent battered the other are particularly powerful tools for resisting requests for joint custody.").

160. Nat'l Council of Juv. \& Fam. Ct. Judges, Model Code on Domestic and Family Violence $\S 401$ (1994).

161. Harris, supra note 159, at 173; see Erin Bajackson, Best Interests of the Child-A Legislative Journey Still in Motion, 25 J. AM. ACAD. MATRIM. LAW. 311, 332-334 (2013) (describing the two legislative approaches).

162. Harris, supra note 159, at 173. The statutes differ in the extent of violence sufficient to trigger the presumption. See, e.g., ALASKA STAT. $§ 25.24 .150$ (g) ("history of perpetrating domestic violence”); ARIZ. REV. STAT. ANN. § 25-403.03(D) ("significant history of domestic violence"); CAL. FAM. CODE $§ 3044$ ("perpetrated domestic violence"); D.C. CODE § 16-914 (commission of an "intrafamily offense"); HAW. REV. STAT. ANN. § 571-46(9) ("family violence"); NEV. REV. STAT. ANN. § 125C.230, 125.480 (“one or more acts of domestic violence"); N.D. CENT. CODE § 14-09-06.2(1)(j) ("pattern of domestic violence”); OR. REV. STAT. ANN. § 107.137 (“committed abuse [one or more acts]”); WASH. REV. CODE ANN. § 26.09.191(1), (2)(a) ("history of acts of domestic violence").

163. Greenberg, supra note 158 , at 415.

164. See id. at 415-431; Nancy Ver Steegh, Differentiating Types of Domestic Violence: Implications for Child Custody, 65 LA. L. REV. 1379, 1379 (2005) ("Family Courts have traditionally turned a blind eye to domestic violence or have minimized its significance."); Dana Harrington Conner, Back to the Drawing Board: Barriers to Joint Decision-Making in Custody Cases Involving Intimate Partner Violence, 18 DUKE J. GENDER L. \& POL'Y 223, 225 (2011) (describing the "heavy burden" the victim needs to meet in order to trigger the presumption. "[S]ome jurisdictions require that the victim prove she suffered physical injuries as a result of abuse, the act is recent, weapons were used in the commission of the act, the act was part of a continuing course of conduct, or that the batterer was convicted of an enumerated offense.").

165. See, e.g., Lawrence v. Lawrence, 20 P.3d 972, 974 (Wash. App. 2001) (“Under the 'friendly parent' concept, primary residential placement is awarded to the parent most likely to foster the child's relationship with the other parent"); NEV. REV. STAT. ANN. $§ 125.480$ (West) (requiring that courts consider "(w)hich parent is more likely to allow the child to have frequent associations and a continuing relationship with the noncustodial parent").

166. See, e.g., Elrod \& Dale, supra note 2, at 394 (describing "how the friendly parent provision is all too often a double-edged sword for parents and children caught in the middle of conflicts."); Ver Steegh, supra note 164, at 1421; Lisa Bolotin, When Parents Fight: Alaska's Presumption Against Awarding Custody to Perpetrators of Domestic Violence, 25 ALASKA L. REV. 263, 278-280 (2008) (describing cases in which the friendly parent provisions blocked appropriate consideration of domestic abuse). 
167. Ver Steegh, supra note 164, at 1421; Bajackson, supra note 161, at 336-337 (describing "Batterers Continuing Control Through the Courts").

168. See, e.g., ALASKA STAT. ANN. § 25.24.150 (West) (directing courts to weigh "the willingness and ability of each parent to facilitate and encourage a close and continuing relationship between the other parent and the child, except that the court may not consider this willingness and ability if one parent shows that the other parent has sexually assaulted or engaged in domestic violence against the parent or a child, and that a continuing relationship with the other parent will endanger the health or safety of either the parent or the child ..."); MINN. STAT. ANN. $\$ 518.17$ (West) ("[E]xcept in cases in which a finding of domestic abuse ... has been made, the disposition of each parent to encourage and permit frequent and continuing contact by the other parent with the child [shall be considered.]")

169. Prof. Barbara Bennett Woodhouse has suggested that the concept of custody itself may be at odds with our modern sensibilities:The law on [child] custody is unique in giving one human being the right to control the body and mind of another, without requiring either the subject person's consent or an individualized finding of lack of capacity. Perhaps this is due to the fact that custody laws have their roots in a social order that established hierarchies of domestic status, treating women, children, and slaves as property of the patriarch. While this society is long gone, children remain the last group subject to legal control based purely on their status. Woodhouse, Child Custody in the Age of Children's Rights: The Search for a Just and Workable Standard, 33 FAM. L.Q. 815, 816 (1999).

170. See Lawrie Moloney et al., Evaluating the Work of Australia's Family Relationship Centres: Evidence from the First 5 Years, 51 FAM. CT. REV. 234, 234 (2013) (describing the reforms).

171. See AMERICAN LAW INSTITUTE, PRINCIPLES OF THE LAW OF FAMILY DISSOLUTION (2002), 2.03 (defining a "parenting plan" as "a set of provisions for allocation of custodial responsibility and decision-making responsibility on behalf of a child and for resolution of future disputes between the parents."); Cynthia Lee Starnes, Lovers, Parents, and Partners: Disentangling Spousal and Co-Parenting Commitments, 54 ARIZ. L. REV. 197, 224 (2012) (decrying custodian and visitor as "hierarchical categories that suggest a zero-sum game").

172. OHIO REV. CODE ANN. § 3109.04 (West).

173. Id.; see § 3109.041 (“" 'joint custody' and 'joint care, custody, and control' have the same meaning as 'shared parenting" ").

174. See MinN. STAT. ANN. § 518.175 (West) (directing the court to "grant such parenting time on behalf of the child and a parent as will enable the child and the parent to maintain a child to parent relationship that will be in the best interests of the child").

175. COLO. REV. STAT. § 14-10-123.

176. Id., § 14-10-124.

177. See, e.g., WASH. REV. CODE ANN. § 26.09.184(1)(a)-(d). The statute mentions counseling, mediation, and arbitration as among the alternative methods. Id., § 26.09.184(4).

178. In re Marriage of Littlefield, 940 P.2d 1362, 1368 (Wash. 1997); see also AMERICAN LAW INSTITUTE, PRINCIPLES OF THE LAW OF FAMILY DISSOLUTION § 2.05 Parenting Plan: Proposed, Temporary, and Final, Comment b. (2002) ("Parenting plans are used increasingly both to encourage parents to plan for their children at divorce and to enable settlement of postdivorce disputes without the necessity of returning to court;" ANDREW I. SCHEPARD, CHILDREN, COURTS, AND CUSTODY: INTERDISCIPLINARY MODELS FOR DIVORCING FAMILIES 45-49 (2004) (discussing parenting plans and joint custody).

179. Nancy Ver Steegh, Family Court Reform and ADR: Shifting Values And Expectations Transform The Divorce Process, 42 FAM. L.Q. 659 (2008). Within the last decade, several alternative dispute resolution (ADR) approaches have emerged to assist in the resolution of child custody disputes. See Daniel B. Pickar \& Jeffrey J. Kahn, Settlement-Focused Parenting Plan Consultations: An Evaluative Mediation Alternative To Child Custody Evaluations, 49 FAM. CT. REV. 59, 59-60 (2011) (discussing collaborative divorce, parenting coordination, impasse-directed mediation for high-conflict divorces, early neutral evaluation, mediation-arbitration, and meditative evaluations). Without a cooperative problem-solving approach, "[p]arents involved in litigation move from being the decision-makers in matters pertaining to their children, to risking the disempowerment that can occur when a third party decides their children's future.") Id. at 59.

180. Peter Salem, The Emergence of Triage in Family Court Services: The Beginning of the End for Mandatory Mediation?, 47 FAM. CT. REV. 371, 371 (2009); see generally J. Herbie DiFonzo, From Dispute Resolution to Peacemaking: A Review of Collaborative Divorce Handbook: Helping Families without Going to Court by Forrest S. Mosten, 44 FAM. L.Q. 95 (2010); John Lande \& Gregg Herman, Fitting the Forum to the Fuss: Choosing Mediation, Collaborative Law, or Cooperative Law for Negotiating Divorce Cases, 42 FAM. CT. REV. 280 (2005). Minimizing "the child's exposure to harmful parental conflict" is another parenting plan objective, as is commitment to a dispute resolution process "other than court action." WASH. REV. CODE ANN. § 26.09.184(1)(e) \& (4). Allocating decision-making authority and incorporating residential provisions for the child are also critical. WASH. REV. CODE ANN. § 26.09.184(5) \& (6).

181. Francis J. Catania, Jr., Learning from the Process of Decision: The Parenting Plan, 2001 BYU L. REV. 857, 870.

182. See ElRoD, supra note 22, at § 5:10 n.1 (listing statutes from Colorado, District of Columbia, Florida, Illinois, Kansas, Missouri, Montana, Nebraska, New Mexico, Oregon, Tennessee, Utah, Washington, and West Virginia). See Trubetzkoy v. Trubetzkoy, 205 P.3d 891 (Utah App. 2009) (reversing the trial court's joint legal custody order because neither parent had filed a parenting plan as required by statute).

183. See ELROD, supra note 22, at $\S 5: 10$ n.2. 
184. FLORIDA STAT. $\S 61.125(1)$. In Florida, the parenting coordinator has a variety of duties, including "assist[ing] the parents in creating or implementing a parenting plan by facilitating the resolution of disputes between the parents by providing education, making recommendations, and, with the prior approval of the parents and the court, making limited decisions within the scope of the court's order of referral. Id.

185. ARIZ. REV. STAT. § 25-403.02(C). In similar fashion, a Florida statute sets out the minimum standards required for a court-approved parenting plan: A parenting plan [must] describe in adequate detail how the parents will share and be responsible for the daily tasks associated with the upbringing of the child; the time-sharing schedule arrangements that specify the time that the minor child will spend with each parent; a designation of who will be responsible for any and all forms of health care, school-related matters including the address to be used for school-boundary determination and registration, and other activities; and the methods and technologies that the parents will use to communicate with the child. FLORIDA STAT. $\S 61.13(2)(b)$.

186. See, e.g., Ga. Code § 19-9-1; Minn. Stat. 518.1705; OR. Rev. Stat. AnN. § 107.102; UtAh Code AnN. § 30-3-10.7. The purposes of the Minnesota Legislature in enacting the parenting plan statute included reducing the number of costly legal conflicts over custody and visitation, decreasing the emotional harm resulting from this type of litigation, enhancing future parental relations, and maximizing both parents' continued involvement in raising their children. Peter V. Rother, Balancing Custody Issues: Minnesota's New Parenting Plan Statute, 57-DEC BenCH \& B. Minn. 27, 27 (2000).

187. In re Marriage of Littlefield, supra note 178 at 1367 (citing statutes).

188. See generally Salem, supra note 180; John Lande, The Revolution in Family Law Dispute Resolution, 24 J. AM. ACAD. MATRIM. LAW. 411 (2012). New Zealand's statute is intended "to encourage parents . . to agree to their own arrangements for the child's care, development, and upbringing." Care of Children Act 2004, Sec. 39, at http://www.legislation.govt.nz/act/ public/2004/0090/latest/DLM317473.html.

189. See, e.g., Divorce Act [Canada] (R.S.C., 1985, c. 3 (2nd Supp.)) ("In making an order under this section, the court shall take into consideration only the best interests of the child of the marriage as determined by reference to the condition, means, needs and other circumstances of the child."); CAL. FAM. CODE $§ 3020$ ("The Legislature finds and declares that it is the public policy of this state to assure that the health, safety, and welfare of children shall be the court's primary concern in determining the best interest of children when making any orders regarding the physical or legal custody or visitation of children."); O’Brien v. O’Brien, 704 So. 2d 933, 935 (La. App. 1997) ("Each child custody case must be viewed in light of its unique facts and circumstances with the principal goal of reaching a decision that embodies the best interest of the child.").Many states have enacted a fairly comprehensive set of statutory factors comprising the best interests test. See, e.g., LA. C. C. ART. 134 (setting out 12 factors for the court to consider in determining the best interests of the child); ARIZ. REV. STAT. ANN. § 25-401 (listing 11 factors); IND. CODE ANN. § 31-14-13-2 (listing eight factors). In some states, case law has substantially expanded the general directions provided by the legislature. For instance, the relevant South Dakota statute commands only consideration of the child's "temporal and mental and moral welfare." S.D. CODIFIED LAWS § 25-4-45. The state supreme court fleshed out those six words into a substantial listing of six multi-faceted factors. Fuerstenberg v. Fuerstenberg, 591 N.W.2d 798, 807 (S.D. 1999).

190. See, e.g., MO. ANN. STAT. $§ 452.375(4)$ (noting "the public policy of this state that frequent, continuing and meaningful contact with both parents after the parents have separated or dissolved their marriage is in the best interest of the child ... and that it is the public policy of this state to encourage parents to participate in decisions affecting the health, education and welfare of their children. ...”); FLA. STAT. ANN. $§ 61.13$ ("It is the public policy of this state that each minor child has frequent and continuing contact with both parents after the parents separate or the marriage of the parties is dissolved and to encourage parents to share the rights and responsibilities, and joys, of childrearing."); TEX. FAM. CODE ANN. § 153.001 (declaring that the "public policy of this state" consists of "assur[ing] that children will have frequent and continuing contact with parents who have shown the ability to act in the best interest of the child; [] provid[ing] a safe, stable, and nonviolent environment for the child; and [] encourag[ing] parents to share in the rights and duties of raising their child after the parents have separated or dissolved their marriage"); 750 ILL. COMP. STAT. ANN. 5/602 (West) ("Unless the court finds the occurrence of ongoing abuse ..., the court shall presume that the maximum involvement and cooperation of both parents regarding the physical, mental, moral, and emotional well-being of their child is in the best interest of the child."). In Australia, there have also been significant legislative reforms to encourage shared parenting, through the Family Law Amendment (Shared Parental Responsibility) Act 2006. One of the objectives of the Family Law Act, as amended by that legislation, is to ensure that "children have the benefit of both of their parents having a meaningful involvement in their lives, to the maximum extent consistent with the best interests of the child."

191. See N.M. STAT. ANN. § 40-4-9.1 ("In any case in which the parents agree to a form of custody, the court should award custody consistent with the agreement unless the court determines that such agreement is not in the best interests of the child"); see also MO. ANN. STAT. $§ 452.375$ (4) (charging the court to "determine the custody arrangement which will best assure both parents participate in such decisions and have frequent, continuing and meaningful contact with their children so long as it is in the best interests of the child.”); ARIZ. REV. STAT. ANN. § 25-403.02 (same).

192. CAL. FAM. CODE $\S 3020$. See id. at $\S 3011$ (noting that any history of child abuse or domestic violence by a parent is a factor to be considered in determining the best interests of the child). Some states have enacted a statutory presumption against awarding legal or physical custody to a parent found to have perpetrated domestic violence. See, e.g., GA. CODE $\S$ 19-9-1; MinN. STAT. § 518.1705; S.D. CODIFIED LAWS § 25-4-45.5; and UTAH STAT. § 30-3-10.7.

193. See, e.g., CAL. FAM. CODE $\S 3040$ (stating that the court "shall not prefer a parent as custodian because of that parent's sex"); N.M. STAT. ANN. $§ 40-4-9.1$ (directing the court not to "prefer one parent as a custodian solely because of gender"); 
Ministry of Justice [New Zealand], Responsibilities for Children Especially When Parents Part, Discussion Paper Aug. 2000, What is the Current Law, at http://www.justice.govt.nz/publications/publications-archived/200 (New Zealand law provides no presumption in favor of one parent over another, nor is the sex of either parent relevant to custody).

194. See WASH. REV. CODE ANN. § 26.09.184 (encouraging parents to meet their responsibilities to their minor children "through agreements in the permanent parenting plan, rather than by relying on judicial intervention ..."); MO. ANN. STAT. $\S$ 452.375(4) (" $[\mathrm{I}] \mathrm{t}$ is the public policy of this state to encourage parents . . . to resolve disputes involving their children amicably through alternative dispute resolution"). The Family Court of New Zealand law advises that parenting agreements are "the best option" for custody cases. Family Court of New Zealand, Parenting Agreements, at http://www.justice.govt.nz/courts/family -court/what-family-court-does/care-of-children/parenting-agreements. Similarly, Australian law encourages parents "to take responsibility for their parenting arrangements and for resolving parental conflict; and ... to use the legal system as a last resort." Family Law Act 1975 [Australia], Sec. 63B, at http://www.austlii.edu.au/au/legis/cth/consol_act/fla1975114/s63b.html.

195. See Fla. STAT. ANN. $§ 61.13$ (specifying minimum detail required in parenting plan); 750 ILl. COMP. STAT. ANN. 5/602.1 (same); Family Law Act 1975 [Austr'l], Sec. 63C, at http://www.austlii.edu.au/au/legis/cth/consol_act/fla1975114/ s63c.html (providing options for inclusion in a parenting plan). Parenting plans should both "optimize the development of a close and continuing relationship between each parent and the child" (TEX. FAM. CODE ANN. $§ 153.601$ ) and minimize "the child's exposure to harmful parental conflict." (WASH. REV. CODE STAT. § 26.09.184(1)(e) \& (4)). Cross-notification and prior consultation are stressed in Maine's statute: "Parents who share parental rights and responsibilities shall keep one another informed of any major changes affecting the child's welfare and shall consult in advance to the extent practicable on decisions related to the child's welfare.” ME. REV. STAT., tit.19-A M.R.S.A. § 1501. Note that parents are often required to draft a parenting plan. If they cannot agree on one parenting plan then each must submit a separate plan. See ARIZ. REV. STAT. ANN. $\S 25-403.02$.

196. See, e.g., WASH. REV. CODE $\S 26.09 .184$ (specifying that a parenting plan is intended to provide each parent's authority and responsibility for the child's physical and emotional well-being, at the time of implementation and as the child ages and matures); Family Law Act 1975 [Australia], Sec. 63C, at http://www.austlii.edu.au/au/legis/cth/consol_act/ fla1975114/s63c.html (noting that a parenting plan may include "the process to be used for changing the plan to take account of the changing needs or circumstances of the child or the parties to the plan").

197. See, e.g., CONN. GEN. STAT. § 46b-56a(d)(3) (noting that parenting plans must include "provisions for the resolution of future disputes between the parents, including, where appropriate, the involvement of a mental health professional or other parties to assist the parents in reaching a developmentally appropriate resolution to such disputes."); ARIZ. REV. STAT. ANN. $\S 25-403.02$ (itemizing eight categories of provisions to be included in all parenting plans); WASH. REV. CODE § 26.09.184(4) (including counseling, mediation, and arbitration as among the alternative methods for dispute resolution).

198. See ARIZ. REV. STAT. ANN. § 25-401 (Joint legal decision-making means that "both parents share decision-making and neither parent's rights or responsibilities are superior except with respect to specified decisions as set forth by the court or the parents in the final judgment or order"); CAL. FAM. CODE $\S 3003$ (Joint legal custody "means that both parents shall share the right and the responsibility to make the decisions relating to the health, education, and welfare of a child."); UTAH CODE ANN. $\S 30-3-10.1$ (joint legal custody "means the sharing of the rights, privileges, duties, and powers of a parent by both parents, where specified"). A judge may "designate one parent to have sole authority to make specific, identified decisions while both parents retain equal rights and responsibilities for all other decisions.” S.C. CODE ANN. § 63-15-210.

199. See MinN. STAT. $§ 518.175(1)(\mathrm{e})$ (providing a "rebuttable presumption that a parent is entitled to receive at least 25 percent of the parenting time for the child"); MO. ANN. STAT. § 452.375(1)(3) (defining joint physical custody as "an order awarding each of the parents significant, but not necessarily equal, periods of time during which a child resides with or is under the care and supervision of each of the parents. Joint physical custody shall be shared by the parents in such a way as to assure the child of frequent, continuing and meaningful contact with both parents ..."); UTAH CODE ANN. § 30-3-10.1 (defining joint physical custody to mean that "the child stays with each parent overnight for more than $30 \%$ of the year").Note that decision-making and parenting time are separate concepts. See ARIZ. REV. STAT. ANN. § 25-403.02 ("[s]hared legal decision-making does not necessarily mean equal parenting time"); UTAH CODE ANN. § 30-3-10.1 (joint legal custody "is not based on awarding equal or nearly equal periods of physical custody of and access to the child to each of the parents, as the best interest of the child often requires that a primary physical residence for the child be designated"). But note also that "[a] parent who is not granted sole or joint legal decision-making is entitled to reasonable parenting time to ensure that the minor child has substantial, frequent, meaningful and continuing contact with the parent unless the court finds, after a hearing, that parenting time would endanger the child's physical, mental, moral or emotional health. ARIZ. REV. STAT. ANN. § 25-403.01.

200. See UTAH CODE ANN. § 30-3-10 (setting out joint legal custody presumption). Australian law encourages parents to take responsibility for their parenting arrangements and to use the legal system as a last resort for resolving disputes; Family Law Act 1975 (Australia), Sec. 61DA, at http://www.austlii.edu.au/au/legis/cth/consol_act/fla1975114/s61da.html ("When making a parenting order in relation to a child, the court must apply a presumption that it is in the best interests of the child for the child's parents to have equal shared parental responsibility for the child.").

201. Adapted from UTAH CODE ANN. § 30-3-10 (joint legal custody presumption); see also Family Law Act 1975 [Australia], Sec. 61DA ("When making a parenting order in relation to a child, the court must apply a presumption that it is in the best interests of the child for the child's parents to have equal shared parental responsibility for the child.").

202. Adapted from CAL. FAM. CODE $\S 3040$ and Mo. ANN. STAT. $§ 452.375$ (setting out order of preference in custody determination). 
203. Adapted from ARIZ. REV. STAT. ANN. § 25-403.01 (setting out measure of parenting time for the parent not provided with joint or sole parenting time allocation).

J. Herbie DiFonzo is a professor of law at the Maurice A. Deane School of Law, Hofstra University. His background includes twenty years of a varied law practice. He teaches courses in family law, civil procedure, and alternatives to litigation, and he writes primarily on issues in family law and juvenile justice. He and Professor Mary E. O'Connell served as the reporters for the Family Law Education Reform Project, a national effort to improve family law teaching, for which he and O'Connell jointly received the 2006 Stanley Cohen Distinguished Research Award. He and Professor Marsha Kline Pruett are currently serving as the reporters for the Association of Family and Conciliation Courts' Think Tank on Research, Policy, Practice, and Shared Parenting, and they are the guest editors for this special issue of Family Court Review. His latest book, coauthored with Ruth C. Stern, is Intimate Associations: The Law and Culture of Families in Twenty-First Century America (University of Michigan Press, 2013). 